\title{
The Chinese Struggle for Civil Rights in Nineteenth Century America: The First Phase, 1850-1870
}

\author{
Charles J. McClain, Jr. $\dagger$
}

Runyon v. McCrary, ${ }^{1}$ an action brought under 42 U.S.C. $\S 1981^{2}$ by black parents whose children had been denied admission to an allwhite private school, gave the Supreme Court in 1976 its first opportumity to construe authoritatively this century-old section of the United States Code. ${ }^{3}$ Among other things, the section guarantees all persons in the Umited States equal rights to make and enforce contracts, but whether it could be used to remedy private acts of discrimination was an unsettled question.

Justice Stewart, writing for the majority and echoing the view of virtually every lower federal court that had ruled on the inatter, ${ }^{4}$

$\dagger$ Vice Chairman, Jurisprudence and Social Policy Program and Lecturer in Law, Boalt Hall School of Law, University of California, Berkeley. A.B. 1964, Xavier University; M.A. 1966, Columbia University; Pls.D. 1972, Stanford University; J.D. 1974, Hastings College of the Law, University of California.

I am indebted to Professors Harry N. Scleiber and Robert C. Berring, Jr. and to my wife Professor Laurene Wu McClain for reading and commenting on earlier drafts of this Article. Any errors or failings in the piece are, of course, iny sole responsibility.

I would like to acknowledge the assistance I received from the staffs of the Bancroft Library, and the Asian American Studies Library, University of California, Berkeley; the California State Archives; and from Mr. Michael Peterson, Librarian at the San Francisco Theological Seminary, San Anselmo, California. I also wish to acknowledge researcl assistance rendered at an early stage of this project by Maureen Young, a graduate student in the Jurisprudence and Social Policy Program at Boalt Hall.

Research for this Article was supported, in part, by an American Bar Foundation Legal History Fellowslip. I am very grateful to the Foundation for its support.

1. 427 U.S. 160 (1976).

2. 42 U.S.C. $\$ 1981$ (1976) provides:

All persons within the jurisdiction of the United States shall lave the same right in every State and Territory to unake and enforce contracts, to sue, be parties, give evidence, and to the full and equal benefit of all laws and proceedings for the security of persons and property as is enjoyed by white citizens, and shall be subject to like punishment, paims, penalies, taxes, licenses and exactions of every kind, and to no other.

3. Though Runyon was the first case in whicls the Supreme Court squarely faced the question of $\S 1981$ 's meaning, it had addressed the issue indirectly on several previous occasions. See, e.g., Georgia v. Rachel, 384 U.S. 780 (1966); see also Jolmson v. Railway Express Agency, 421 U.S. 454 (1975); Jones v. Alfred H. Mayer Co., 392 U.S. 409 (1968).

4. The major federal cases construing $\S 198 \mathrm{I}$ before Runyon are Young v. IT\&T, $438 \mathrm{~F} .2 \mathrm{~d}$ 757, 760 (3d Cir. 1971); Waters v. Wisconsin Steel Works of Int'l Harvester Co., 427 F.2d 476, 482 (7th Cir.), cert. denied, 400 U.S. 911 (1970); Scott v. Young, 421 F.2d 143, 145 (4th Cir.), cert. 
found $^{5}$ that the code section derived from section 1 of the Civil Rights Act of $1866 .{ }^{6}$ That statute, according to the Court, had been enacted pursuant to Congress' implied power, under section 2 of the thirteenth amendment, to pass legislation aimed at elimmating the "badges and incidents of slavery."7 One of the statute's purposes, Stewart wrote, was to bar private discrimination in the making of contracts; therefore, the Runyon plaintiffs had a legitimate cause of action under section $1981 .^{8}$

Whatever one may think of the ultimate outcome of the case, it is quite clear that the Court seriously misread the legislative history of section 1981. The evidence is simply indisputable, as Justice White recognized in his lengthy dissenting opmion, ${ }^{9}$ that section 1981 derives from section 16 of the Civil Rights Act of $1870,{ }^{10}$ a statute that was not designed - at least not in any primary sense-to promote the civil rights of the nation's newly emancipated black citizens, but rather to respond

denied, 398 U.S. 929 (1970). See also Cook v. Advertiser Co., 458 F.2d 1119 (5th Cir. 1972) (no jurisdiction under $\S 1981$ because forms completed by plaintiff did not constitute a contract).

5. Runyon, 427 U.S. at 168-69. Dicta in two Jones footnotes indicated that the Court believed that $\S 1981$ was derived from $\S 1$ of the 1866 Act. Jones, 392 U.S. at 422 n.28, $441-42$ n.78. It was not until Runyon that this became a holding.

6. Civil Rights Act of 1866 , ch. $31, \S 1,14$ Stat. 27,27 (1865-67). Section 1 provided: That all persons born in the United States and not subject to any foreign power, excluding Indians not taxed, are hereby declared to be citizens of the United Statcs; and such citizens, of every race and color, witlout regard to any previous condition of slavery or involuntary servitude, except as a punishment for crime whercof the party shall have been duly convicted, shall have the same right, in every State and Territory in the Unitcd States, to make and enforce contracts, to sue, be parties, and give evidence, to inherit, purchase, lease, sell, and convey real and personal property, and to full and equal benefit of all laws and proceedings for the security of person and property, as is enjoyed by white citizens, and shall be subject to like punishment, pains, and penalties, and to none other, any law, statute, ordinance, regulation, or custon, to the contrary notwithstanding.

7. The Civil Rights Cases, 109 U.S. 3, 20 (1883).

8. Runyon, 427 U.S. at $170-73$.

9. Id. at 192 (White, J., dissenting).

10. Civil Rights Act of 1870 , ch. $114, \S 16,16$ Stat. 140, 144 (1869-71). Section 16 provided: That ail persons within the jurisdiction of the United States shall have the same right in every State and Territory in the United States to make and enforce contracts, to sue, be parties, give evidence, and to the full and equal benefit of all laws and proceedings for the security of person and property as is enjoyed by white citizens, and shall be subject to like punishment, pains, penalties, taxes, licenses, and exactions of every kind, and none other, any law, statute, ordinance, regulation, or custom to the contrary notwithstanding. No tax or charge shall be imposed or enforced by any State upon any person innigrating thereto froin a foreign country which is not equally imposed and enforced upon every person immigrating to such State froun any other foreign country; and any law of any State in conflict with this provision is hereby declared null and void.

When United States statutes were codified in 1874, the first sentence of $\S 16$ became, with a minor clrange, $\S 1977$ of the 1874 Revised Statutes. 24 Rev. Stat. $\S 1977$ (1873-75). The change involvcd dropping the last phrase of the sentence, beginning with "any law ...." The codificrs put the second sentence under the title on immigration, omitting the last clause that declares conflicting state laws null and void. $29 \mathrm{Rev}$. Stat. $\S 2164$ (1873-75). The language of 42 U.S.C. $\S 1981$ is taken verbatim from $\S 1977$ of the 1874 Revised Statutes. 
to the phight of another aggrieved racial mmority-the Chincse of California. ${ }^{11}$

That the Supreme Court and the other federal courts that considered section 1981 should, despite abundant evidence, be oblivious to the section's Chinese origms is not surprising. The Court's error in Runyon is but one sign pointing to a much larger phenoinenon: the at best obscure niche which the Chinese occupy in the historical consciousness of the average educated American. ${ }^{12}$ It is generally known that thousands of Chinese immigrants came to the west coast in the second half of the nineteenth century-initially to work California's newly opened gold fields, later to labor on the construction of the transcontinental railroad and im other trades. Some niay know as well that their presence came to arouse hostility in the white population and that this hostility was eventually translated into discriminatory legislation. But there general familiarity ends. Only the inost unusual federal niagistrate, it seems fair to say, would be alert to the possibility that the Chinese could have had anything to do with the enactment of Reconstruction-era civil rights legislation.

American historiography bears a large part of the responsibihty for this state of affairs. In the first place, niost accounts of the great Chinese immigration to the Uirited States in the nineteenth century have concentrated exclusively on the reaction it provoked in the white population; they have tended to ignore the Chinese and their perception of their experience in this country. ${ }^{13}$ As one commentator has

11. Justice White, joined by Justice Rehnquist, disputed the majority's assertion that $\S 1981$ was designed to deal with acts of purely private racial discrimmation. My purpose here is not to enter into the debate on the merits of the Court's ultimate holding in Runyon. Instead, I take issue with the Court's rendition of the legislative history of $\$ 1981$, which utterly ignores the role the Chinese had in the enactment of the provision.

12. One exception to the general obliviousness of federal courts to the Asian origins of $\S 1981$ is Cook v. Advertiser Co., 323 F. Supp. 1212, 1216-17 (M.D. Ala. 1971), aff'd, 458 F.2d 1119 (5th Cir. 1972). For law review commentary on $\S 1981$, see Note, Federal Power to Regulate Private Discrimination: The Revival of the Enforcement Clauses of the Reconstruction Era Amendments, 74 Colum. L. Rev. 449 (1974); Note, Desegregation of Private Schools: Section 1981 as an Alternative to State Action, 62 Geo. L.J. 1363 (1974); Note, Association, Privacy and the Private Club: The Constitutional Confict, 5 HARv. C.R.- C.L. L. Rev. 460 (1970); Note, The Desegregation of Private Schools: Is Section 1981 the Answer?, 48 N.Y.U. L. Rev. 1147 (1973); Note, Section 1981 and Private Groups: The Right to Discriminate Versus Freedom from Discrimination, 84 YALE L.J. 1441 (1975). None of these pieces indicates any awareness of the Chinese background of the statute. But see Note, Section 1981 and Private Discrimination: An Historical Justification for a Judicial Trend, 40 GEO. WASH. L. REv. 1024, 1029-31 (1972) (recognizing the statute's Chinese origins).

13. Standard accounts of the white reaction to the Chinese presence are M. CoolidGE, Chinese Immigration (1909); L. Eaves, a History of California labor legislation (1910); S. MILleR, THE UNWElCOME IMMIGRANT: THE AMERICAN IMAGE OF THE CHINESE 17851882 (1969); E. Sandmeyer, The Anti-Chinese Movement in California (1939); A. Saxton, The INDispensable Enemy: Labor and the ANTi-Chinese Movement in CALifornia (1971). Sandmeyer's 1939 monograph remains the best overview of the evolution of official policy toward 
aptly put it, "Other immigrant groups were celebrated for what they had accomphished; Orientals were important for what was done to them."14 Furthermore, the Chinese have not fared very well even at the hands of those scholars who have sought to deal with them as subjects of history and not as mere objects. The few scholarly writings that have focused on the Chinese community have tended to be deprecatory, emphasizing what is usually described as the authoritarian, hierarchical structure of Chinese society; the corruption or ineptitude of the leadership; and the passivity, docility, and otherworldliness of the Chinese masses. ${ }^{15}$ These writings make inuch of what they see as the unique character of the Chinese immigration. The Chinese, so the arguinent goes, unlike all other immigrant groups, did not come to this country with a desire to settle and assimilate, but rather with the intention to make a quick fortune and return home. It was this feature of their immigration, according to this view, that was inost responsible for the misfortunes that were visited upon thein. White Californians had offered the hand of welcoine to the newcomers from Asia but were rebuffed because these immigrants had no interest in staying or being acculturated. ${ }^{16}$ Having inade overtures of goodwill and having seen them ungenerously rejected by the ethnocentric Chinese, the white inajority population then turned on the Chinese and determined to exclude then "from the privileges and obligations of other immigrants"17 - a strange gloss on the history of Oriental-Caucasian race relations, it is submitted, in view of the overt hostility that has characterized so inuch of white America's actions toward the Chinese from a very early period of contact between the two races.

A very important corollary of the sojourner theme is the notion that the nineteenth century Chinese community had utterly no interest

the Chinese in California. I am inuch indebted to it for background. The Coolidge study, a turn of the century work by a native Californian, is remarkable for its sympathetic treatment of the Chinese.

14. Daniels, Westerners from the East: Oriental Immigrants Reappraised, 35 PAC. Hist. REv. 373,375 (1966). For a very good effort to capture the Chinese perception of their experience in America, see V. G. Nee \& B. De Bary Nee, Longtime Californ': A Documentary Study of AN AMERICAN ChINATOWN (1972).

15. See, e.g., G. Barth, Bitter Strength: A History of the Chinese in the United STATES, 1850-1870 (1964), the only im-depth scholarly study of the early history of the Chinese in California. Barth describes the Chinese as "the docile subjects of bosses and headmen, still directed in California by the dictates of the Chinese world." Id. at 1.

16. "For the vast inajority of sojourners, these overtures lacked significance in relation to their aim to make money quickly, to pay off their indenture, and to return to their families." Id. at 5 .

17. Id. at 1. Despite the strong exception that this Article takes to the overall thrust of Barth's book, it must be stressed that the work is a valuable source of information on the structure and organization of the 19 th century Chinese community. For a variation on the sojourner theme, see K. Zo, Chinese Emigration into the United States, 1850-1880 (1971). 
in American political institutions or desire to adapt itself to thein. This has been a leitmotif of commentary on the nineteenth century Chinese community since its origins. The typical Chinese immigrant, wrote San Francisco's Daily Alta California in 1869, "knows and cares nothing inore of the laws and language of the people aniong whon he lives than will suffice to keep him out of trouble and enable him to drive a thrifty trade in the vocation which he chooses." "18 And Supreme Court Justice Stephen Field ${ }^{19}$ observed in 1884 that "Our institutions have made no impression on [the Chinese] during the more than thirty years they have been in the country." 20 One finds the sanie thenie repeated in modern scholarship as well. The Chinese community is pictured as indifferent to the larger political milieu in which it was placed-and this despite the succession of unpleasant burdens that that milieu was imposing on it. ${ }^{21}$ Mainstreain scholarly literature on the Chinese consistently einphasizes the group's insularity and political isolation. ${ }^{22}$

18. Citizen John Chinaman, Daily Alta California, July 24, 1869, at 2, col. 1. The Alla was the leading California newspaper at the time. Another newspaper of the period echoed the same notion, claiming that the Chinese had "no idea of our institutions, even in but a shight degree." Horace Davis and the Six Companies, [San Francisco] Daily Evening Post, Jan. 21, 1878, at 2, col. 1 .

This view of the Chinese was also shared by the legislators of the time. For example, a congressional committee in 1877 informed the full body that the Chimese had neither knowledge of nor appreciation for American political institutions. JolNT SPECIAL CoMm. To INveStigate Chinese Immigration, S. Rep. No. 689, 44th Cong., 2d Sess. vii (1877).

19. Field, whose home state was California, and who sat on several of the relevant cases as a California Supreme Court justice, as a federal circuit court judge, and, finally, as United States Supreme Court Justice, was well aware that the Chinese were making effective use of one American institution-the courts-to advance their interests. See Fritz, Bitter Strength (k'u-li) and the Constitution: The Chinese Before the Federal Courts in California, HIST. REP., Autumn 1980, at 2 (published by the Historical Society of the United States District Court for the Northern District of California). For examples of some early Chinese cases on which Justice Field sat, see infra notes $174-86$ and accompanying text.

20. Chew Heong v. Uinted States, 112 U.S. 536, 567 (1884) (Field, J., dissenting).

21. Barth, for example, states that the Chinese community, qua community, failed to appreciate the severity of the legal restrictions under which it operated or to respond to them in any significant way. He sees this as but another evidence of lack of acculturation. G. BARTH, supra note 15, at 179-80. He acknowledges that one can find individual instances of resistance to political oppression but sees these merely as efforts on the part of scattered persons to attain their own goals. Bitter Strength deals only with the period 1850-70. The book suggests that there was more Chinese interest in acculturation later in the ceutury.

In his monograph, Zo depicts the Chinese community as politically apathetic and inactive. He attributes the problem to the community's merchant leadership, which he describes as provincial and dull. K. Zo, supra uote 17, at 190-91.

22. One scholar who gives a kind of a back-handed recognition to the political consciousness of the Chinese is Howard Jay Graham. In his major study of the constitutional jurisprudence of the late 19th century, Everyman's Constitution, Graham recognizes the great significance for constitutional history of the numerous Chinese "civil rights" cases decided by federal courts in the 1870 's and 1880 's. He sees these cases, however, as being brought mainly to advance the interests of the large corporations, especially the railroads, rather than the Chimese. H. GRAHAM, EverYMAN's Constitution 571 (1968). These cases, of course, are beyond the scope of this Article, though in a later study I imtend to deal in detail with these cases and with Graham's gloss on 
A inajor purpose of this Article is to suggest that standard interpretations of the Chinese experience in America are in great need of revision. While the Chinese community was certainly more isolated from mainstream American society than other ethnic groups in the nineteenth century, lack of political consciousness was not one of its inost sahent characteristics. Notwithstanding the conventional wisdoin, there is ample evidence ${ }^{23}$ to show that the Chinese, from the very earhest days of the immigration and throughout the nineteenth century, were keenly aware both of their political surroundings and of American governmental institutions. They made repeated effortsinany abortive but many others stunningly successful-to use those institutions to proinote their interests. In the course of doing so they made immensely important contributions to American pohtical and legal history, contributions which to date have been largely ignored. The Chinese gave formidable demonstration of their political acumen in the period 1870-1890, when they used one governmental institution-the courts - to vitiate virtually every anti-Chinese measure enacted by the State of California and its municipalities. But even in the earliest phase of the immigration, there were notable developments and clear signs of Chinese pohtical sophistication. We concentrate here on the period 1850-1870 and on the events that eventually led Congress to enact section 16 of the Civil Rights Act of $1870 .^{24}$

I

THE RISE OF RESENTMENT IN THE EARLY 1850's

The first Chinese to arrive in California were greeted with a mixture of enthusiasm and curiosity. They were few in number and

them. At this point, suffice it to say that I belicve Graham's views are incorrect. To see the Chmese primarily as stalking horses for large industrial interests is to badly misconstruc 19th century Chinese-American history. Some evidence suggests that Chinese community leaders saw some, though by no means all, leaders of the Caucasian business community as natural allies and worked with them when that appeared to inure to their own benefit. However, there is no evidence to indicate that Caucasian business interests were manipulating the Chinese or were the imstigating force behind the many efforts undertaken by the Chimese to vindicate their claims for civil rights, whether in the judicial or the legislative branch of government.

23. It will be noticed that all of the evidence cited in this study is in English and that there are no citations to Chinese materials. Any scholar doing research on the early history of the Chinese in America confronts the sad fact that there are practically no extant sources in Chinese on this period. Unfortunately, 19 th century records of the various Chinese community institutions were very bikely casualties of the 1906 earthquake and fire, which destroyed Chinatown. In seeking to piece together a picture of the Chinese reaction to Amcrican society, onc inust rely almost entirely on Enghish-language sources. Even so, under careful analysis these sources are extremely revealing.

24. This is the first installment of what is intended to be a comprehensive treatment of the contribution of the Chinese to the development of American law, a project on which iny wife Laurene $\mathrm{Wu}$ MeClain and I are collaborating. 
seemed a harmless and exotic addition to the cosmopolitan mass of humanity that was gathering in Northern Califorma in the wake of the discovery of gold at Sutter's Mill. In August 1850, for example, on the occasion of the ceremonies held in San Francisco to observe the death of Zachary Taylor, the city fathers invited the local Chinese to send a contingent to participate in the rites and assigned it a prominent place in the funeral cortege. ${ }^{25}$ Many local observers noted with great satisfaction the large Chinese presence two inonths later at the San Francisco celebrations of California's admission to the Union. ${ }^{26}$ And in a January 1852 address to the California Legislature, Governor John McDougal endorsed the importation of Chinese for the purpose of draining California's immense swainplands, describing them as "one of the inost worthy classes of our newly adopted citizens-to whoin the climate and the character of these lands are peculiarly suited."27

This spirit of hospitality lasted but a brief time, lowever. As the number of Chinese grew, their presence caine to be deeply resented, especially in the state's mining districts where they concentrated. Many explanations have been offered for the hostility-and no doubt there is a grain of truth in each of them. ${ }^{28}$ But the ultimate reasons for the resentment were quite simple and are nicely summarized in a most revealing passage from Theodore Hittell's History of California, published in 1897:

As a class, [the Chinese] were harunless, peaceful and exceedingly industrious; but, as they were reinarkably economical and spent little or none of their earnings except for the necessaries of life and this chiefly to merchants of their own nationality, they soon began to provoke the prejudice and ill-will of those who could not see any value in their labor to the country. ${ }^{29}$

In short, they worked too liard (often for less pay than others were willing to accept), saved too mucli and spent too little. In addition, they looked and behaved differently from the inajority population. Beneath all the surface rationalizations, this was to be the gravamen of the complaint against the Chinese through the inany phases of the antiChinese movement in California.

\section{A. Calls for Legislation}

As early as 1852, agitation coininenced in some of the mining regions to stem the inflow of Chinese workers and to expel those who

25. 4 T. HitTell, History OF CALIforNiA 98-99 (1897).

26. Id.

27. G. BARTH, supra note 15 , at 136 .

28. See, e.g., L. EAVES, supra note 13, at 105-17.

29. 4 T. HitTELL, supra note 25 , at 99 . 
were already settled. The agitation first bore fruit in a report issued in April 1852 by a Cahifornia Assembly committee. ${ }^{30}$ The report identified as the preeminent evil threatening the well-being of the mining districts "the concentration, within our State hmits, of vast numbers of the Asiatic races, and of the inhabitants of the Pacific Islands, and of many other dissimilar from ourselves in customs, language and education." ${ }^{.31}$ Most of these persons, the report stated, had not come to California voluntarily but rather had been inported as servile labor by foreign capitahists and were held to labor under contracts not recognized by American law. ${ }^{32}$ They had no desire to become American citizens (or if they did it was not wise to encourage them in this wish), and their presence demeaned American laborers already in California and deterred the immigration of additional (white) citizens. The report urged legislative action at the national and state levels to deal with the problem. Specifically it suggested that California might, in imposing its Foreign Miners' License Tax, ${ }^{33}$ differentiate between those who had declared their intention of becoming Annerican citizens and those who had no such intention. ${ }^{34}$

\section{B. Gubernatorial Support}

Governor John Bigler, the state's third chief executive, gave a inuch more powerful impetus to the anti-Chinese moveinent when, one week later, he dehivered a special message to the legislature on the evils

30. Assembly Comm. on Mines and Mining Interests, Report, Cal. Assembly, 3d Sess., Appendix to the Journals 829 (1852).

31. Id. at 830. Though the report concentrated on Chinese immigrants, it also viewed with alarm the presence of those it described as "Mexican and South American peons." Id. at 835.

32. Id. at 831. In March 1852, for reasons that are not entirely clear, Senator George Timgley introduced a bill that would have allowed for enforcement in California of long-term, fixed-wage, labor contracts made in China. Since the bill resembled indentured servitude, it got nowhere in the legislature. See G. BARTH, supra note 15, at 136-38. It did, however, provide ammunition to anti-Chinese demagogues for many years to come.

Though in the early years of the immigration there were a few instances of Chinese coming to this country under contracts of labor for terms of years, the overwhelming majority of Chinese did not come under an obligation to work for any particular employer. Many, to be sure, had had their passage to California financed by lenders in China, and repayment of these debts was enforced in various ways by the institutions of Chinese society in America. These institutions also facilitated the einployinent of Chinese who were looking for work. On this, see, e.g., G. BARTH, supra note 15, at 55-57; M. CoOLIDGE, supra note 13, at 51-54; see also infra note 57.

33. In 1850, the California legislature lad enacted a law, aimed not only at the Chinese but at all foreigners, that required all who were not native-born citizens of the United States or who had not acquired citizenship by the Treaty of Guadaloupe-Hidalgo, to pay a fee of $\$ 20$ per month for the privilege of working in the state's mines. Act of Apr. 13, 1850, ch. 97, $\$ 1,5,1850 \mathrm{Cal}$. Stat. 221, 221-22. Though the constitutionality of the ineasure had been upheld in a landmark California Supreme Court decision, People v. Naglee, 1 Cal. 232 (1850), it had proved impossible to enforce and was soon repealed. Act of Mar. 14, 1851, ch. 108, 1851 Cal. Stat. 424.

34. ASSEMbly COMm. ON Mines AND Mining InTERests, Report, supra note 30, at 834. 
of the immigration from Asia. ${ }^{35}$ Extraordmary measures were needed, the governor said, to "check [the] tide of Asiatic immigration,"36 which he saw threatening to inundate the state, especially in the mining districts. He called particular attention to the widely held belief that the mass of the Chinese immigrants were bound to long contracts of indentured servitude ("coolie labor") and that in some cases their families in China were held hostage to the faithful performance of these contracts. ${ }^{37}$

The legislative program he recommended to stop immigration from Asia contamed two main elements: a request to the Congress to enact a bill making contracts for coohe labor unenforceable ${ }^{38}$ and the enactment of a state taxation prograin that would fall heavily on the Chinese and thus tend to discourage their continued presence. He also suggested-though he did not push the point quite as hard-that the state had the right to use its police power to prohibit completely Chinese immigration into Cahfornia or at the very least to bar the Chinese from working in the state's mimes. ${ }^{39}$ Most ominously, though he did not include such a proposal in the recommended legislative agenda, Bigler suggested that California's Asian immigrants, since they were indifferent to the solenin obligations of an oath, ought not to be allowed to serve as jurors or to testify in court. 40

Though Bigler doubtless spoke for a large segment of the population, ${ }^{41}$ his harangue did not go without opposition. For exainple, the state's leading newspaper, San Francisco's Daily Alta California reacted quite coolly to the governor's proposals. In a lengthy commentary published the day after Bigler's message, the paper, while allowing that a vastly increased Chinese population miglit at some point pose problems for the state, refused to see the existing situation as troublesome or one that required urgent legislative attention. ${ }^{42}$ It described the Chinese as being "as industrious, as moral, and as orderly as any

35. It was the first of several such messages to come from Bigler and the first in a long series of anti-Chinese pronouncements that were to emanate from the state capital over the course of the 19 th century.

36. Governor's Special Message, Daily Alta California, Apr. 25, 1852, at 2, col. 2.

37. Elsewhere in the message, Bigler noted that he had no hard information about the terms of these contracts and as much as admitted that he was reporting runors. Id.

38. A decade later, in 1862 , Congress enacted a law prohibiting the importation of coolie labor. Act of Feb. 19, 1862, ch. 27, 12 Stat. 340.

39. Bigler recognized that much of what he was advocatimg came close to encroaching on the federal government's exclusive jurisdiction over foreign commerce; but he argued for the program's constitutionality and, in any case, strongly hinted that this was no time to be imdulging constitutional scruples. Governor's Special Message, supra note 36.

40. Id.

41. Every element of the legislative program Bigler outlined was eventually enacted mto law by the Cahfornia Legislature.

42. The Chinese Immigration, Daily Alta California, Apr. 26, 1852, at 2, col. 1. 
other class of our population" and saw them as a net benefit to the state's economy. Finally, it expressed grave reservations about the wisdom and constitutionahity of Bigler's legislative proposals. ${ }^{43}$

Significantly, a few days later the paper pubhshed an open letter to Bigler from one Norman Asing, a San Francisco Chinese 1nerchant and self-described naturahzed citizen and Christian. ${ }^{44}$ Asing came right to the point:

[T] he effects of your late message has been thus far to prejudice the public mind against my people, to enable those who wait the opportumity to hunt them down, and rob thein of the rewards of their toil. You may not have meant that this should be the case, but you can see what will be the result of your propositions. ${ }^{45}$

He fiatly denied that California had any right under the Constitution to restrict immigration and took strong issue with Bigler's assertion that the Chinese were inehigible to become American citizens. ${ }^{46}$ "The declaration of your independence, and all the acts of your government,

43. Id. According to Hittell, Bigler's attack upon the Chinese was considered very offensive and uncalled for by "some of the most intelligent and liberal-minded classes of the counmunity." 4 T. HITTELL, supra note 25 , at 108.

44. Little is known about Asing (sometimes spelled Assing) except that he was a man of substantial power and mfluence in the early Chinese community in San Francisco and was perceived by the white population as a leader and a spokesman. He is portrayed in Barth's inonograph as a somewhat sliadowy flgure who exercised tight and autoeratic control over his countrymen and whose rule was widely resented. G. BARTH, supra note 15, at 83-85. Whatever the truth of these cliarges, Asing's rejoinder to Bigler was cogent, eloquent and more than a little feisty.

45. Asing, To His Excellency Gov. Bigler, Daily Alta California, May 5, 1852, at 2, col. 2.

46. Although it had not been settled by autloritative judicial decision at the time, it was almost universally believed that the Chinese could not avail themselves of the federal naturalization laws to beeoine American citizens. The belief was based on language in the naturalization statute, which inade only a "free white person" eligible for naturalization. Act of Apr. 14, 1802, cl. 28,2 Stat. 153, 153, repealed and superseded by Act of June 29, 1906, eh. 3592, $\$ 26,34$ Stat. 596,603 . The notion also found support in a well-known passage in Chancellor Kent's Commentaries on American Law. There, the great early 19th century jurist, construing the naturalization statute, had expressed doubt whether any of the "yellow or tawny races of Asiatics" could ever becoine citizens. 2 J. Kent, COMMENTARIES ON AMERICAN LAW 72 (3d ed. 1836). Relying on these authorities, the California Supreme Court in its decision in People v. Hall, 4 Cal. 399 (1854), declared categorically that the Chinese could become neither eleetors of California nor citizens of the United States. Since the right to citizenship was not an issue in Hall, the court's statement was pure dictum; but some Californians felt the case lad disposed of the matter. (In fact, Hall eoncerned the competency of Clinese people to testify as witnesses in court, and the decision was extremely inportant. See infra notes 108-30 and accompanying text.)

Final resolution of the citizenship question came in 1878 when United States Cireuit Judge Lorenzo Sawyer lield, in a test case brought by the Chinese, that Chinese residents could not use the existing naturalization statutes to becoine Ameriean citizens. In re Ah Yup, 1 F. Cas. 223 (C.C.D. Cal. 1878) (No. 104). (Sawyer so held despite an 1870 ainendinent to the naturalization statute that extended citizenship eligibility to "aliens of African nativity and to persons of African descent." Act of July 14, 1870, ch. 254, § 7, 16 Stat. 254, 256.)

Ah Yup illustrates a perduring conundrum that the Chinese faced throughout the 19th century. They were accused of having no interest in American politieal institutions, but when they souglit to demonstrate any imterest, they were considered arrogant and uppish. When Ah Yup 
your people, and your history, are against you," he wrote. ${ }^{47}$ For Bigler's characterization of the Chinese as a degraded and inferior race he showed the coldest contenpt. The Chinese could be considered degraded, he said, only if the desire to work hard in an honest trade was degraded. And on the question of ethnic inferiority, Asing begged to remind the governor "that when your nation was a wilderness, and the nation from whom you sprung barbarous, we exercised most of the arts and virtues of civilized life." 48

\section{The Imposition of Discriminatory Taxes}

No doubt partially in response to Bigler's message and the agitation in the mining districts against the Chinese and other foreign miners, the legislature passed a bill in May 1852 reenacting the almost forgotten Foreign Miners' License Tax. ${ }^{49}$ The new measure-captioned, mterestingly, "An Act to Provide for the Protection of Foreigners, and to define their liabilities and privileges"-set the license fee at $\$ 3$ per month and directed that revenues be split equally between the state and the counties where the mines were located. ${ }^{\text {so }}$ It denied access to the courts to anyone who did not have a license, ${ }^{51}$ and authorized the sheriffs of affected counties to appoint deputies to assist them in collecting the tax. ${ }^{52}$

In the same inonth the legislature enacted another measure that becaine known as the "commutation tax."53 It is clear from the context of the times that this tax was aimed primarily at the Chinese, though like the miners' tax it did not mention them by name. But wliere the Foreign Mmers' License Tax was implemented to burden the pursuit of the mining trade by the Chinese who were already in California (and

sought to assert his citizenship rights, the general reaction of the white population was one of horror and revulsion.

47. Asing, supra note 45.

48. Id. (emphasis in original). Apparently other Chinese responded to Bigler, and they drew favorable comment. "[T] hey evinced a decided superiority to [Bigler] not only in temper but also in logic." 4 T. Hittell, supra note 25, at 108 (citing F. Soule, J. Gihon \& J. Nisbet, The ANNALS OF SAN FRANCISCO 381 (1855)).

49. Act of May 4, 1852, ch. 37, 1852 Cal. Stat. 84, repealed and superseded by Act of Mar. 30, 1853, ch. 44, 1853 Cal. Stat. 62 (officially repealed, Act of Apr. 26, 1939, ch. 93, 1939 Cal. Stat. 1067, 1215); see supra note 33.

50. Act of May 4, 1852, ch. 37, $\S \S 6,9,1852$ Cal. Stat. 84, 85 .

51. Id. $\$ 10,1852$ Cal. Stat. at 86 .

52. Id. $\$ 8,1852 \mathrm{Cal}$. Stat. at 85 . This last provision was to lead to severe abuses that had deadly consequences for the Chinese simce these deputies had a tendency to exact the fee in a rather violent manner. Joint Select Comm. Relative to the Chinese Population of the State of CALIFoRNIA, REPORT, 13th Sess., Appendix to the Journals 7 (1862) [hereinafter cited as JoINT SELECT COMM. REPORT].

53. Act of May 3, 1852, ch. 36, 1852 Cal. Stat. 78, amended by Act of Apr. 2, 1853, ch. 51, 1853 Cal. Stat. 71 (officially repealed, Act of Apr. 27, 1945, ch. 111, § 5, 1945 Cal. Stat. 424, 465). 
thereby to give them incentive to leave), the commutation tax was designed to discourage their coming im the first place. The act, as amended the following year, required the masters of all vessels arriving at California ports to prepare a list of all foreign passengers and the owners of the vessels to post a $\$ 500$ bond for each of these passengers. The bond could be commuted by the payment of $\$ 5$ to $\$ 10$ per passenger. $^{54}$ Other provisions required the master to specify further whether any of the incoming passengers were mentally ill or disabled and empowered the mayor to require an additional bond in these cases. ${ }^{55}$ In practice, the bond was routinely commuted by the payment of the $\$ 5$ fee, the sum having been simply added as a surcharge to the basic price of passage. The Chinese passengers, $\mathrm{m}$ other words, bore the full burden of the act.

\section{Chinese Reaction}

At first, there was no notable opposition in the Chinese cominumity to either the 1852 hicense legislation or the commutation tax. The Chinese were apparently willing to bear the taxes which seemed relatively modest in ainount and appeared to offer the prospect of defusing soine of the amimosity felt towards them by the state's majority population. $^{56}$ It was a mistaken calculation on their part. The anti-Chinese agitation continued unabated, especially in the gold-mining districts, and im the next session of the legislature several bills were introduced in the assembly to increase radically the amount of the license or to exclude foreigners coinpletely from the mimes. The bills were referred for consideration to the Coinmittee on Mines and Miming Interests, which was also charged with the inore general task of gathering information on the state's Chinese population.

In what doubtless was an effort to head off the threat of draconian legislation, the heads of the Chinese community's four major district associations ${ }^{57}$ contacted the cominittee through their attorney and re-

54. Id. $\$ \S 1-3$ ( $\$ 1$ as amended, 1853 Cal. Stat. 71-72). In New York v. Miln, 36 U.S. (11 Pet.) 102 (1837), the United States Supreme Court had upheld a New York law requiring shipmasters to report foreign passeager identification.

55. Act of May 3, 1852, ch. $36, \S \S 1,5,1852$ Cal. Stat. 78,80 (§ 1 as amended, 1853 Cal. Stat. 71-72). The tax was to remain in effect until 1872, when it was declared unconstitutional by the California Supreme Court. State v. S.S. Constitution, 42 Cal. 578, 590 (1872).

56. L. EAvEs, supra note 13, at 112 .

57. Virtually all Chinese belonged to a district association. There were several well-demarcated districts in the Canton area, the region of Chima from which most 19th century immigrants came; and identification with and loyalty to the district of origin were deeply ingrained in the inhabitants. When the Chinese arrived in California, they organized into district associations. Among their functions were assisting new immigrants to find employment, providing for tempo- 
quested an interview. ${ }^{58}$ The committee acceded to the request and conducted a series of interviews with these representatives in San Francisco.

The committee's report of these interviews ${ }^{59}$ offers compelling evidence of the well-developed pohtical sensitivity of the Chinese community leadership even at this early date. The heads of the district associations ${ }^{60}$ came well prepared for these nieetings. They supplied copious information on the size, niakeup and social organization of the Chinese community in Califorma, information which refuted the charge of the existence of a system of indentured servitude and which

rary lodging and board, arbitrating disputes between the members, and enforcing debts owed by the immigrants to creditors in China who had financed their passage over.

In the early 1860's, the Cahfornia district associations organized a coordinating council. One of the council's inain jobs was to adjudicate disputes between Chinese from different districts, but it came quickly to serve, as well, as chief intermediary between the Chinese community and the larger white society. Each district organization was represented on the council, and the council presidency rotated between the heads of the various district associations. While the official English name adopted by the council was the Chimese Consolidated Benevolent Association, and while at various times as few as four and as many as eight district associations were represented, the organization became popularly known as the Chinese Six Coinpanies. The Six Companies was unquestionably the most important organization in Chinese-Anerican society in the 19th century. For background on the Six Coinpanies, see W. Hoy, The Chinese Six Companies (1942); see also G. BARTH, supra note 15, at 77-100; V. G. NEE \& B. DE BARY NeE, supra note 14, at 65-67; The Six Chinese Companies, 1 OverLand MONTHLy Sept. 1868, at 221-27.

Later, in a period beginning about 1870 and continuing through the end of the century, the Six Coinpanies sponsored a great deal of Chinese civil rights litigation. It sponsored, for example, the lawsuit that succeeded in overturning one of the inost spiteful and malicious laws ever enacted by the city of San Francisco, the so-called "Queue Ordinance", which in effect mandated the cutting off the queues of all Chinese committed to the county jail. See Ho Ah Kow v. Nunan, 12 F. Cas. 252 (C.C.D. Cal. 1879) (No. 6546). It is perhaps worth noting that one of the grounds relied on by the court in this case was $\S 1977$ of the 1874 Revised Statutes, now codified as 42 U.S.C. $\$ 1981$ (1976). Id. at 256; see also supra note 10.

58. It is, of course, highly significant that as early as 1853 , if not earlier, the Chinese of California had a lawyer on retainer. Eaves comments, perceptively, "They had learned at this early date the advantages of einploying an able lawyer to present their side of the situation . . . ." L. EAVES, supra note 13, at 108.

In the same vein, the Daily Alia California, in an account of a habeas corpus action involving Chinese petitioners accused of violating a municipal ordinance, made this highly interesting observation: "The Chinese fee the lawyers better than any other class of citizen and every honorable ineans will be taken by the learned counsel who have been engaged in these cases to acquit their clients." The Chinese Cases, Daily Alta California, Apr. 25, 1854, at 2, col. 2. Relatedly, withm inonths after the first Chinese coinmunity formed in San Francisco, it approached local San Francisco attorney Selim Woodworth and asked him to act as its "adviser and arbitrator," a proposal he accepted. Meeting of the Chinese Residents, Alta California, Dec. 10, 1849, at 1, col. 4. Woodworth was elected to the Cahfornia Senate in 1849.

59. Assembly Comm. ON Mines and Mining INTERests, Report on the Chinese Population, Doc. No. 28, Cal. Assembly, 4th Sess., Appendix to the Journal of the Assembly 9 (1853) [hereinafter cited as REPORT ON THE CHINese Population].

60. Gee Atai and Lee Chuen represented the Sze-yup Company; Tong K. Achick and Lum Teen-Kwei represented the Yeong Wo Company; Tam Sam and Chun Aching represented the Canton Company; and Wong Sing and Lee Yuk Nain represented the Suwon Coinpany. Tong K. Achick acted as interpreter. Id. 
gave a very roseate picture (no doubt too roseate) of the democratic character of Chinese-American society and the benevolence of its leadership. ${ }^{61}$ Referring to the committee's legislative agenda, the association leaders offered a proposal which they averred might persuade the people of the mining counties that the Chinese presence among them was a benefit rather than a burden. They expressed no opposition to an mcrease im the miners' tax if the legislature felt it was necessary, but they did suggest that the revenue so generated be left entirely with the counties where it was collected rather than be split witl the state. ${ }^{62}$

They also laid boldly and frankly before the committee a list of grievances of which they said their countrymen complained. Chief among them was the increasing violence to which they were being subjected in the mining districts. The several association houses had kept records of the numerous instances of violent attacks on Chinese by white uniners, and the committee, based on its own observations, attested to the correctness of these reports. ${ }^{63}$ The association leaders complained, too, of a large number of instances in which courts of justice had not accepted the testimony and statements of Chinese witnesses because of the color of their skins. It was wrong, they declared, for the state to tax them and at the same time to withhold "that protection which is implied in the payment of taxes."64 A point on which they were quite insistent was, in the committee's words, "that some settled and certain policy should be pursued towards their people [so] their persons and property may in fact as well as in law, occupy the same position as the persons and property of other foreigners."65 It was a point that they would make time and again and that they would eventually see embodied both in statute ${ }^{66}$ and $\mathrm{m}$ court decision. ${ }^{67}$

The statement of grievances was logical, well reasoned and obviously well prepared. It appealed to the committee's sense of justice and equity. If this were not enough, the inerchant leaders of the Chmese community also added an appeal to the committee members' more worldly concerns. They assured the committee that if the Chinese grievances were addressed, "trade and commerce between the two countries [would] imcrease, . . . capital now lying dormant in Chma

61. Id. at 7-10.

62. Id. at 10 .

63. Id. at 9.

64. Id.

65. Id. at 10 (emphasis in original).

66. Civil Rights Act of 1870, ch. 114, § 16, 16 Stat. 140, 144 (1869-71).

67. See, e.g., In re Tiburcio Parrott, I F. 481 (C.C.D. Cal. 1880) (voiding California law imposing criminal sanctions on anyone employing a Chinese or Mongolian person); Baker v. City of Portland, 2 F. Cas. 472 (C.C.D. Or. 1879) (No. 777) (voiding Oregon law prohibiting employment of Chmese on street improvement or public works projects). 
... [would] here seek investment in private trade and public improvements, and in fact [in] everything in the State that gives fair promise of its safe and profitable employinent." 68

The intervention of the heads of the company houses was to good-albeit temporary-effect. The committee urged rejection of the proposals for radical change in the license laws. The tone and thrust of the report contrasted markedly with the committee's report of the previous year. The majority considered groundless the apprehension felt by some that the Chinese would soon inundate the state and crowd out the white population. ${ }^{69}$ Moreover, the legislators thought it a libel on the national character to suggest that Americans could not compete with Asian immigrants. ${ }^{70}$ The report also spoke of the detrimental effects that anti-Chinese legislation might have on trade with China which both the state and national governments were interested in promoting. ${ }^{71}$ Ultimately, the committee recommended only that the monthly license fee be increased by $\$ 1,{ }^{72}$ a recommendation that the full legislature duly enacted into law. ${ }^{73}$

\section{II}

\section{New Hostility and New Responses}

\section{A. Additional Taxes}

The Chinese were not long able to savor this modest legislative success. Anti-Chinese hostility was-at this phase of its history-like a stubborn brush-fire, whose flames could be dampened but never quite put out. In its very next session the legislature amended the original miming laws to exempt from the licensing requirement those who had declared their intention to become American citizens, ${ }^{74}$ thus eliminat-

68. Report on the Chinese Population, supra note 59, at 10. In its report on proposed legislation, the committee spoke of a desire "to allure to our shores the vast accumulations of Asiatic capital which are the result of ages of labor and economy." ASSEMBLY COMM. ON MINES and Mining Interests, Report on the Proposed Legislation, Doc. No. 28, Cal. Assembly, 4th Sess., Appendix to the Journal of the Assembly 6 (1853) [heremafter cited as REPORT ON THE Proposed Legislation].

In these mid-century decades many Cahfornians harbored hopes of a great two-way trade with the Chinese Empire, and saw the prosperity of the state tied to that trade. The Chmese played deftly on these hopes from time to time.

69. The report spoke of the peculiar imfluences which tended to keep the Chinese at home. Report ON The Proposed Legislation, supra note 68, at 5.

70. "The superior energy of the Caucasian will always conquer the sullen industry of the Mongal [sic]." Id.

71. Id.

72. Id. at 3.

73. Act of Mar. 30,1853 , ch. $44, \S 6,1853$ Cal. Stat. 62,63 (officially repealed, Act of Apr. 26, 1939, ch. 93, 1939 Cal. Stat. 1067, 1215).

74. Act of May 13, 1854, ch. 49, 1854 Cal. Stat. 55 (Redding) (amending 1853 Cal. Stat. 62) (officially repealed, Act of Apr. 26, 1939, ch. 93, 1939 Cal. Stat. 1067, 1215). 
ing any doubt that the act was aimed at oppressing the Chinese. ${ }^{75}$ On the same day, May 13,1854, the legislature passed a concurrent resolution, requesting Cahifornia's Congressional delegation to seek Congressional authorization for a California statute that would impose a direct capitation tax on all natives of China and Japan entering the state. ${ }^{76}$

The following year brought further legislative action. Furious, ugly agitation in the mining regions, especially Shasta County, prompted both houses of the legislature in 1855 to empanel select committees to examine again the question of Chinese miners. The assembly committee recominended that the Chinese be flatly barred from working in the mines of California. ${ }^{77}$ This unsubtle proposal proved too extreme to win the assent of either house, but the measure enacted was only shightly less severe. It provided for an imcrease in the license fee to $\$ 6$ per month, effective October 1,1855 , and a ratcheting up by an additional $\$ 2$ per inonth on October 1 of each succeeding year ad infinitum.$^{78}$ If a sudden expulsion of the Chinese from the mines offended the scruples of too many legislators, the use of confiscatory taxation to gradually squeeze thein out over time did not.

The legislature also noved to discourage further immigration of new Chinese miners. On April 28, 1855 Governor Bigler approved a bill captioned "An Act to Discourage the Immigration to this State of Persons Who Cannot Becoine Citizens Thereof," which imposed on the master or owner of each vessel landing passengers "incoinpetent by the laws of the United States or the laws and constitution of this State to become citizens thereof ${ }^{79}$ a tax of $\$ 50$ for each such passenger. ${ }^{80}$ As noted, less than a year earher the legislature, doubtless aware of the serious constitutional questions raised by a direct state tax on iminigration, ${ }^{81}$ had urged California's representatives in Congress to solicit the

75. See supra note 46.

76. Cal. Con. Res. of May 13, 1854, 1854 Cal. Stat. 230 (Redding).

77. Assembly Select COMM. ON Foreign Miners, Majority Report on Assembly Bills No. 206, $207 \&$ 208, Doc. No. 19, Cal. Assembly, 6th Sess., Appendix to Journal of the Assembly (1855).

78. Act of Apr. 30, 1855, ch. 174, 1855 Cal. Stat. 216 (amending 1853 Cal. Stat. 62), repealed by Act of Apr. 16, 1856, ch. 119, § I, 1856 Cal. Stat. 141.

79. See supra note 46.

80. Act of Apr. 28, 1855, ch. 153, 1855 Cal. Stat. 194 (officially repealed, Act of Mar. 30, 1955, ch. 46, § 1, 1955 Cal. Stat. 487, 488). A minority of the senate select coininittee recommended imposing the tax on the Chinese "upon their landing in the country [because] it will be difficult if not impossible for them to pay it." SENATE SElect COMM., MinoRity REPORT ON Resolutions of Miner's Convention of Shasta County, Doc. No. 16, Cal. Senate, 6th Sess., Appendix to the Journal of the Senate 5 (1855). The minority thought that by making it nearly impossible for additional Chinese to immigrate to Cahifornia those already in the state would be mduced to leave. The Chinese were already complaining about the legislature's oppressive acts, the report noted. $I d$. at 7 .

81. The United States Supreme Court in The Passenger Cases, 48 U.S. (7 How.) 282 (1849), 
national government's approval for the enactment of such a law. ${ }^{82}$ However, it apparently was in no mood to wait very long for a reply and decided to take direct action itself. The 1855 session was perhaps the high-water mark of anti-Chinese sentiment in the legislature for the entire decade. ${ }^{83}$

\section{B. Allies in the White Community}

\section{Overturning the Capitation Tax}

The 1855 anti-Chinese measures were enacted impetuously, in response to the impassioned pleadings of a rather small, but very vocal, sector of the population. The larger body politic did not take long in voicing its displeasure. Edward McGowan, the state's Commissioner of Immigrants, informed the legislature that some provisions of the capitation tax were unconstitutional and that he had no intention of enforcing them. ${ }^{84}$ And in February 1856 some one hundred San Francisco merchants sent the legislature a memorial supporting the commissioner and decrying the policy of discouraging Chinese immigration as detrimental to the interests of the state. ${ }^{85}$ Finally, the shipping companies which stood to sustam enormous financial losses if the act were enforced ${ }^{86}$ determined to challenge tlie measure in court. The outcome was hardly in doubt, and in 1857, when People v. Downer ${ }^{87}$ came before the California Supreme Court, it took the justices less tlian half a page of the reports to void the nreasure as an impermissible interference with the national government's power over foreign commerce.

\section{Criticism of the Miners' Tax}

The drastic increase in the mimers' tax also provoked considerable disquiet after the public realized its full effects. Since enactment of the first foreign miners' license legislation the Chinese had been faithfully

had struck down a state law imposing a tax on alien passengers arriving from foreign ports. Eight separate opinions were written and the exact basis of the decision was none too clear.

82. Cal. Con. Res. of May 13, 1854, 1854 Cal. Stat. 230 (Redding). See supra text accompanying note 76.

83. As bleak as the session proved to be for the Chinese, it is interesting to note that two of the Chinese district associations, the Sze Yap and Ning Yeung Companies, were able to secure passage of a special bill permitting them to own, buy and sell real property and enter into contracts in their own names. Act of Apr. 30, 1855, ch. 159, 1855 Cal. Stat. 202. The measure was necessary because neither organization was incorporated.

84. See Assembly Comm. ON Mines and Mining Interests to Whom was Referred the Memorial of Citizens of San Francisco, Report, Cal. Assembly, 7th Sess., Appendix to the Joumal of the Assembly 5 (1856).

85. Id. at 3 .

86. There was simply no way that the shipping companies could pass on such a steep tax$\$ 10$ more than the full cost of passage from China-to their Chinese passengers.

87. 7 Cal. 169 (1857). 
and punctually paying their license fees and, not incidentally, had been enriching the treasuries of both the state and many of its counties. ${ }^{88}$ Many people, even in the mining counties, began to wonder whether it was altogether wise for state and local governments to drive the Chinese out through excessive taxes, thereby depriving themselves of a steady, reliable source of revenue. The legislature soon began receiving calls from the mining districts asking for reconsideration of the harsh inining license legislation. Representatives of the state's busmess classes, convinced that the immigration represented the opening phase of a potentially limitless cominercial intercourse with the Chinese Empire, began to urge reconsideration as well. And for the first time Protestant missionaries began to speak out im behalf of the Chinese. Chief among these was the Reverend William Speer.

Speer was a Presbyterian missionary who had labored in China for several years before voyaging to San Francisco in 1852 to open a mission in that city. He was fluent in Cantonese and quickly became a friend and confldant of the leaders of the local Chinese community. Like many missionaries, he larbored hopes of Christianizing the immigrant unasses and seeing them return to China to spread the good word alnong their fellow countrymen. Like most missionaries of the era, he was capable of being quite patronizing toward the Chimese, but unlike inost, he counterbalanced this with a thorough understanding of Chinese history and a glowing admiration for the grand cultural attainments of Chinese civilization. ${ }^{89} \mathrm{He}$ was deeply conservative in his political values, and one of the things that attracted him most in the Chinese was their thrift and willingness to work hard for modest remuneration..$^{90} \mathrm{He}$ was, above all, genumely repelled by the coarse racism and demagoguery of the anti-Chinese movement and spoke out against it repeatedly during his four-year sojourn in Cahfornia. He was on the

88. According to figures compiled in $\mathbf{1 8 5 6}$ by the Controller of the State, the state had received $\$ 429,434$ in license fees through the end of 1855. El Dorado County, one of the most important mining counties, lad received $\$ 102,426$ during a three-year period from 1853 to 1855 . Senate Comm. on Mines and Mining Interests, Majority Report, Cal. Senate, 7th Sess., Appendix to the Journal of the Senate 6 (1856). These were very large sums of money for the time and often accounted for more than $10 \%$ of government revenues. See, e.g., CoNTROLLER of State, Statement of Receipts, 1855 Annual Report, Doc. No. 2, Cal. Senate, 7th Sess., Item A, Appendix to the Journal of the Senate (1856).

89. Reverend Speer's attitude toward the Chinese and his knowledge of their history and culture are clearly evidenced in his book, W. SPEER, THE OLDEST AND THE NEWEST EMPIRE: China AND THe United STATeS (1870). For information on Speer generally, see Stahler, William Speer: Champion of California's Chinese, 1852-57, 48 J. PRESBYTERIAN HIST. 113 (1970).

90. Interestingly, in the first issue of Speer's bilingual newspaper, The Oriental: or Tung. Ngai San-Luk, he made the prophetic suggestion that the Chinese, industrious and experienced in the building of large projects, would be an excellent source of labor for the construction of the proposed Trans-Pacific Railway. Laborers for the Pacific Railroad, The Oriental, Jan. 4, 1855, at 2, col. 1. 
whole a cogent, eloquent, and effective advocate in behalf of Chinese interests. ${ }^{91}$

In January 1855 , Speer began to publish a newspaper, The Oriental: or Tung-Ngai San Luk, which appeared thrice weekly in a bilingual edition and on a daily basis in Chinese for the next two years. The paper contained its share of moral uplift literature and unvarnislied sectarian propaganda, but it considered as equally important missions the refinement of American feeling toward the Chinese and the overturning of hostile legislation. It campaigned actively in these causes as well. Speer spoke out against the mining legislation of 1855 both in The Oriental and in a special pamphlet which he prepared and had circulated in Sacramento. ${ }^{92}$ He offered testimony from certain miners' license fee collectors that the fees were already oppressing many Chinese miners ${ }^{93}$ and pleaded that they be reduced again to $\$ 4$ per month. ${ }^{94}$ Any policy aimed at excluding or debasmg Chinese immigration, he argued, was detrimental to the interests of the state and unworthy of the people of a great nation. ${ }^{95}$

\section{Legislative Repeal}

In response to lobbying of this sort, bills were introduced in the 1856 session of the legislature to repeal the 1855 law and to reduce the Foreign Mmers' License Tax to $\$ 4$ per montl. The standing mining committees of both houses took up the measures and issued separate reports recommending reduction of the tax. ${ }^{96}$ In tone the two reports, however, were as might and day, and they stand agam as testimony to the divided, fluid, and changeable character of political opimion on the Chinese question at the time. ${ }^{97}$ The senate document breathed a spirit of openness and sympathy for the Chinese. It spoke of "the presence of this unfortunate people in our midst," 98 reminded the legislature that the Chinese had come to California by implied invitation at least, and

91. Unfortunately, no critical biography of Speer exists.

92. W. Speer, An Humble Plea Addressed to the Legislature of California in Behalf of the IMmigrants from the Empire of China to This State (1856).

93. Id. at 32-33.

94. Id. at 32 . Speer also argued for reducing the passenger tax froin $\$ 50$ to $\$ 5$.

95. Id. at 5 .

96. Senate Comm. on Mines and Mining INTERests, supra note 88; Assembly Comm. ON MINES AND MINING INTERESTS, REPORT, Cal. Assembly, 7th Sess., Appendix to the Journal of the Assembly (1856). One had to read the Assembly report very carefully to see that this was the recominendation.

97. In the period 1850-70, the mood of the legislature was mercurial. In some sessions nary a voice was heard in behalf of the Chinese. In others, a fair number of legislators spoke in their behalf.

98. Senate Comm. ON Mines AND Mining InTERests, supra note 88, at 3. The thoughts, if not the language of the report resonated perfectly with the pamphlet prepared by Speer. See supra notes $92-95$ and accompanying text. 
commented that it ill became "a proud, powerful, and magnanimous nation to oppress any one, least of all a class of defenseless strangers." 99 It pointed out as well that it was especially mean spirited to begrudge the Chinese miners their gams since they worked generally in marginal diggings that had been abandoned by other miners. ${ }^{100}$

In contrast, the assembly report was thoroughly hostile to the Chinese, stating that their presence was "neither beneficial nor desirable; but on the contrary, highly detrimental to the welfare, safety and happiness of the State."101 Elsewhere, the report described them as a "distimct and inferior race," 102 "horribly depraved," 103 and "verily a nation of hars . . . unworthy of credit." 104 The report even foreshadowed the soon-to-become familiar charge that the Chinese dishonored and degraded labor. ${ }^{105}$ The report's concluding paragraph, which recommended, in only the most opaque language, a inonthly tax of $\$ 4$, seeined strangely out of joint with the rest of the document. ${ }^{106}$ Still, on April 19, 1856, the legislature repealed the act of 1855 and reset the foreign miners' license fee at its former level of $\$ 4$ per month. ${ }^{107}$

III

\section{The Right to Bear Witness}

If the proposed miners' tax increase threatened the ability of Chinese to earn a living, a decision that came down from the California Supreme Court in December 1854 represented a threat, quite literally, to life and limb. As noted, Chinese leaders as early as 1853 had complained to the legislature about the exclusion of testimony from Chinese witnesses in certain state courts. ${ }^{108}$ Concern heightened as the number of crimes committed against Chinese in the mining districts increased and as the conviction deepened that potential perpetrators were being emboldened by the good chance that their victims would be forever unable to testify against them.

\section{A. A Disgraceful Decision: People v. Hall}

In August 1853, the grand jury of Nevada County returned an in-

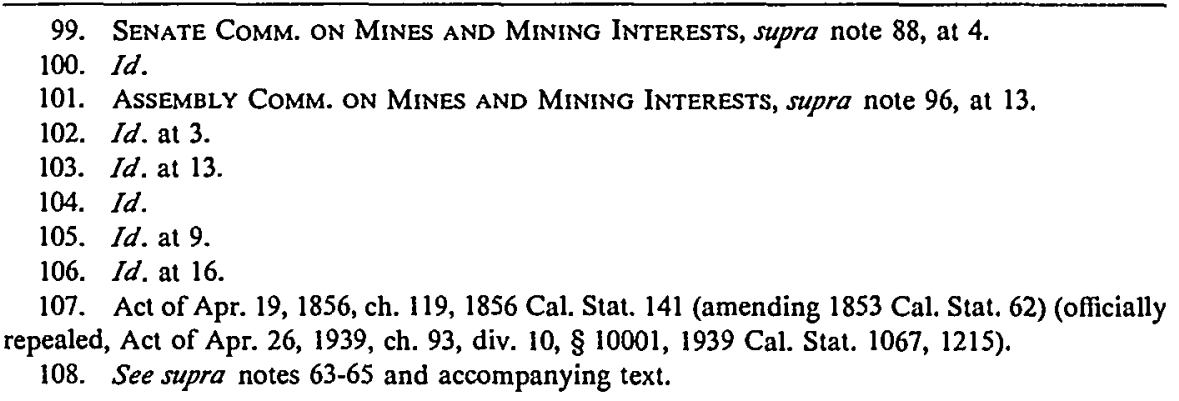


dictinent against George W. Hall and two others for the inurder of one Ling Sing. ${ }^{109}$ In October, a four-day trial was held, during which three Chinese and one Caucasian witness testified on behalf of the state. ${ }^{110}$ The jury returned a verdict of guilty, and Hall was sentenced to be hanged. ${ }^{111}$ Counsel for the defendant appealed the verdict on the ground, annong others, that the Chinese witnesses should not have been heard against his client, and for the first time the question of testimonial capacity of Chinese immigrants was presented to the state's highest court for adjudication.

Chief Justice Hugh C. Murray, in an opinion that must surely rank as one of the most disgraceful in the armals of California appellate jurisprudence, held that the Chinese testiniony had been inproperly received and the conviction must be reversed. ${ }^{112}$ The decision was based on three grounds: on canons of statutory construction, as the court purported to understand them; on a kind of amateur foray into history and ethnography; and on what the court called public policy considerations.

The court first purported to construe a California criminal statute which provided that "No black or inulatto person, or Indian, shall be permitted to give evidence in favor of, or against, any white person." 113 Relying on its understanding of history, the court reasoned that upon touching ground at San Salvador, Columbus thought that he had found "an island in the Chinese Sea," lying near the extremity of India. Actmg on this supposition, he had given the islanders the name "Indians." "From that time, down to a very recent period," wrote the court, "the American Indians and the Mongolian, or Asiatic, were regarded as the same type of the human species." 114 Scientists, the court continued, had until quite recently beheved that Indians and Asians came from the same ethuric stock. ${ }^{115}$ While granting that most scientists no longer beheved that North America had originally been populated by immigrants from Asia, the court said that California law was based on earlier enacted legislation from other states that had clearly treated

109. Indictment at 1, People v. Hall, 4 Cal. 399 (1854) (on file with the California Law Review).

110. Interestingly, Reverend Speer acted as interpreter for the Chinese witnesses. Trial Transcript at 1, People v. Hall, 4 Cal. 399 (1854) (on file with the California Law Review).

111. Id.

112. Hall, 4 Cal. at 399.

113. Act of Apr. 16, 1850, ch. 99, $\S 14,1850$ Cal. Stat. 229, 230, amended by Act of Mar. 18, 1863 , ch. 70,1863 Cal. Stat. 69 , repealed by omission from codification CAL. PENAL CODE $\S 1321$ (1872) (officially repealed, Act of Mar. 30, 1955, ch. 48, § 1, 1955 Cal. Stat. 488, 489). A paraliel, but not identical provision, applied to testinony in civil cases. Civil Practice Act of 1851, ch. 5, $\$ 394(3)$, 1851 Cal. Stat. 51, 114, amended by Act of Mar. 16, 1863, ch. 68, 1863 Cal. Stat. 60, repealed by omission from codification CAL. Crv. PROC. CODE $\$ \$ 8,1880$ (1872) (officially repealed, Act of Mar. 30, 1955, ch. 33, § 1, 1955 Cal. Stat. 475, 475).

114. Hall, 4 Cal. at 400.

115. Id. at $400-01$. 
Chinese and Indians as being of the same stock. ${ }^{116}$ Further, even assuming that Asians were not the same as Indians, the word "black" in the statute, said the court, inust be understood in the generic sense as excludimg all races other than Caucasians. ${ }^{17}$

Finally, quite apart from reasons of statutory construction, Murray stated that he felt compelled to reach his decision on pubhic pohicy grounds. If the Chinese were admitted to the witness stand, he wrote, we would "soon see thein at the polls, in the jury box, upon the bench, and in our legislative halls," 118 a prospect that inust have filled him with something bordering on horror since he considered the Chinese "[a people] whose mendacity is proverbial; a race ... nature has marked as inferior, and . . . incapable of progress or intellectual development beyond a certain point ...."119 Thus the court, confronted with an odious law, had chosen to expand rather than restrict its apphication. ${ }^{120}$

\section{B. Reaction to Hall}

The Chinese reacted quickly and vocally to the Hall decision. Lai Chun-Chuen, a prominent San Francisco merchant, attacked the decision in an open letter to Governor Bigler prepared in January 1855, primarily in rcsponse to an anti-Chinese speech by the governor. ${ }^{121} \mathrm{On}$ Hall the letter was indignant and characteristically ethnocentric:

[O]f late days, your honorable people have established a new practice.

They have come to the conclusion that we Chinese are the same as Indians and Negroes, and your courts will not allow us to bear witness. And yet these Indians know nothing about the relations of society; they know no mutual respect; they wear neitlier clothes nor shoes; they live in wild places and [m] caves. ${ }^{122}$

The Chinese, by contrast, had a record of thousands of years of honor and civilization. ${ }^{123}$ The decision to bar Chinese testimony by equatimg

116. Id. at 402 .

117. Id. at 403-04.

118. Id. at 404 .

119. Id. at 404-05.

120. The Hall construction of the term "Black . . . person, or Indian" was applied to § 394(3) of the Civil Practice Act five years later in Speer v. See Yup Co., 13 Cal. 73 (1859). Citing Hall, the court took only two sentences to affirm dismissal of a breach of contract action that was based on testimony from Chinese people. The party Speer in the case was not the Rev. William Speer; it was one James Speer, who is otherwise unknown.

121. Lal Chun-Cheun, Remarks of the Chinese Merchants of San Francisco Upon GovernoR BIGLER's MESSAGE 5 (W. Speer trans. 1855) (available in Bancroft Library, University of California, Berkeley). The letter, prepared on behalf of the Chinese Merchants' Exchange of San Francisco and widely circulated in the Chinese merchant community, offered a point-bypoint refutation of the charges inade against the Chinese by the governor.

122. Id.

123. Id. 
them with blacks and Indians, said Lai, could not have been the result of "enlightened intelligence and enlarged liberality."124 Nor was reaction confined to the merchant strata of Chinese-American society. The minority report of a state senate committee noted, for example, that there was widespread resentment in the Chinese community at the refusal of courts to allow them to testify. ${ }^{125}$

As was to be expected, Speer's Oriental editorialized vigorously agamst the supreme court decision in Hall. "The principles of Magna Charta, the prerogatives of juries, the rights of judges and advocates, Republicanism, Christianity, and common humanity are all outraged by this iniquitous decision of the Supreme Court of California," thundered Speer. ${ }^{126}$ But Speer's was not the only Caucasian voice to be heard speaking in behalf of the Chinese. In fact the ban on Chinese testimony was a source of deep embarassment to the more civilized elements of white society, and some of the leading organs of Caucasian opinion, to their credit, spoke out forthrightly against it. ${ }^{127}$ When a cainpaign was mounted in the late 1860's to overturn Hall in the legislature, the leadimg newspapers were in the vanguard. ${ }^{128}$ Protests, however, were to no avail, and in 1863 the legislature added insult to injury by codifymg the Hall decision ${ }^{129}$ and extending the principle to civil cases as well. ${ }^{130}$

Of all the wrongs visited upon the Chinese in the period from 1850 to 1870 , the ban on their testimony-not surprisingly, given its fateful implications-rankled most deeply. The removal of this disability was consistently the chief item on the agenda of the community leadership. Speer informed the California legislature in 1857, in a pamphlet aimed at overturning Hall, that the testiniony ban was the "greatest stumbling block" preventing the Chinese from fully enjoying California's

124. Id. The letter was translated into Enghish by Reverend Speer and circulated as a pamphlet in the state capital. A History of the SAM YUP Benevolent Association in the United STates 1850-1974, at 16 (Y. Oy, H. Lai \& P. Choy eds. 1975).

125. SenAte Select CoMm., supra note 80 , at 7 .

126. Chinese Testimony, The Oriental, Jan. 18, 1855, at 3, col. 1 .

127. Three years later, when lamenting the assembly's defeat of a bill that would have reversed the Hall result, the Daily Evening Bulletin commented, "We regret this action, based as it is entirely upon prejudice, and can only express our conviction that the period will ultimately arrive when it will be clear to all that the law as it stands is mischievous and prejudicial in the highest degree to the public interests." Admissibility of Chinese and Negro Testimony, San Francisco Daily Evening Bulletin, Apr. 10, 1857, at 2, col. 1.

128. See infra notes $193-95$ and accompanying text.

129. Act of Mar. 18,1863 , ch. $70,1863 \mathrm{Cal}$. Stat. 69 , repealed by omission from codification Cal. Penal Code $\S 1321$ (1872) (officially repealed, Act of Mar. 30, 1955, ch. 48, $\$ 1,1955$ Cal. Stat. 488, 489). Presumably because of the Civil War, a proscription on black testimony was not included in the 1863 codification.

130. Act of Mar. 16, 1863, ch. 68,1863 Cal. Stat. 60 , repealed by omission from codification CAL. Civ. Proc. Code $\S \S 8,1880$ (1872) (officially repealed, Act of Mar. 30, 1955, ch. 33, § 1, 1955 Cal. Stat. 475, 475). 
prosperity. ${ }^{131}$

Particularly interesting evidence not only of Chinese sensitivity on the subject but of a determination to do something about it is found in two remarkable letters written in January 1860 by the Reverend A. W. Loomis, Speer's successor as head of the San Francisco mission to the Chimese, to the Presbyterian Board of Foreign Missions in Philadelphia. In the first of these letters, ${ }^{132}$ Loomis wrote that he had been approached the previous Sunday after services by six Chmese, representing the Chinese district associations, who said that they had some matters that they wished to lay before him. He related that he tried to put them off but that under pressure he agreed to meet with them the next day. At the meeting they told him that his predecessor Speer had routimely interested himself im political matters affecting the Chimese and that they now wished his assistance. They told him specifically, Loomis wrote, that "they would like some laws altered, especially those excluding Chinamen from the privilege of testifymg im the courts" and requiring payment of the miners' tax. ${ }^{133}$ Loomis related that, while lee did not wish to become too involved in politics, he did inform the Chinese leaders that lie would try to be of assistance and that in the meantime they slould write up petitions expressing their grievances. He told the Board of Foreign Missions that what the Chinese needed was "a good man to lobby for them" in the legislature ${ }^{134}$ and that he intended to see if he could locate such a person.

At the end of the month Loomis wrote again to his superiors in Pennsylvania to inform them of the results of his efforts. In this letter, ${ }^{135}$ Loomis amiounced that he had found a lawyer-indeed a former city judgc ${ }^{136}$ - to attend to the imterests of the Chinese in Sacramento, that the heads of the company houses had agreed to his ternıs, ${ }^{137}$ and that the lawyer had already cominenced work in the state capital. Loomis' later correspondence with the Board of Foreign Missions makes no further references to this episode, ${ }^{138}$ and so one cannot say

131. W. Speer, Answer to Objections to Chinese Testimony and Appeal for their PROTECTION BY OUR LAWS I (1857) (available in Bancroft Library, University of California, Berkeley).

132. Letter from Rev. A.W. Loomis to Hon. Walter Lowrie (Jan. 3, 1860) (on file with the California Law Review).

133. Id.

134. Id. (emphasis in original). Loomis added, however, that "as the case now stands, I fear they have a diin prospect." Id.

135. Letter from Rev. A.W. Loomis to Hon. Walter Lowrie (Jan. 30, 1860) (on file with the California Law Review).

136. Unfortunately, the judge's identity remains a inystery. We know only that he was "an elder in Dr. Anderson's church." Id.

137. Interestingly, the terms called for payment of expenses and a fee contingent upon the lawyer's success. Id.

138. No external evidence on the question exists either. 
for how long a period the lawyer-lobbyist remained the Chinese representative in Sacramento. In all probability the relationship did not endure for very long since fees were to be paid only if the lobbying was successful and, as noted earher, this was not an auspicious time for the Chinese in the halls of the state legislature. The episode, however, clearly demonstrates the well-developed political consciousness of the Chinese community leadership at this very early stage of Chinese settlement in America.

The issue of the ban on Chinese testimony was to flare imto prominence agaim toward the end of the 1860's. Meanwhile, other events were transpiring in the early part of the decade.

\section{IV}

\section{TaXation and Challenge in the Early 1860's}

\section{A. The Legislature}

In early 1862 the legislature empaneled a joint select committee, consisting of three senators and three assemblymen, to confer with the Chinese merchants of California ${ }^{139}$ and to report back to the full body on the wisdom of permitting a permanent Chinese presence in the state. The charge was similar to the cliarge that the legislature had given a decade earlier to the Committee on Mines and Mining Interests, and the 1862 report that the coinmittee issued ${ }^{140}$ was, in its uniformly proChinese thrust and tone, quite reminiscent of the earlier committee report. ${ }^{141}$ In view of the quantum growth of Sinophobia in the intervening ten years, the latter is the inore striking of the two documents and, in retrospect, seems almost a historical anomaly. Significantly, it was to be the last report sympathetic to Chinese interests to issue from any organ of California State government for the duration of the nineteenth century.

The committee told the legislature that the approximately 50,000 Chmese then working in Cahifornia were a distinct economic asset to the state. The Chinese mercliants, the report stated, were "men of imtelligence, ability, and cultivation, who [had] kindly and promptly [responded to the committee's] many inquiries." 142 They were peaceable, patient, and imdustrious, and they were helping to build the state "by contributing largely to our taxes, to our shipping, farning, and meclramical interests." 143 Instead of seeking to discourage their presence, the state ought to encourage them to stay and pursue their la-

139. The legislature took for granted that the merchants were the leaders of the community.

140. Joint Select Comm. Report, supra note 52.

141. Report on the Proposed Legislation, supra note 68, at 5.

142. JoInt Select Comm. Report, supra note 52, at 3.

143. Id. at 6 . 
bors. ${ }^{144}$ Nor was there any foundation to the charge that they represented a threat to white interests. No evidence indicated that Chinese were displacing white labor. They did not mingle with whites. Indeed, they did not even have the most basic civil rights, such as the right to testify in court, that were possessed by the lowliest Caucasian. "Certainly we have nothing to fear from a race so contemned and restricted," said the authors. ${ }^{145}$

The committee saw no need for further legislation on the Chmese and took the legislature to task for the hostile laws then on the books, laws which it believed ${ }^{146}$ ran counter to the spirit and letter of an 1858 treaty between the United States and China. ${ }^{147}$ "The present laws in force in regard to this class of our population," the committee declared, "impose upon then quite as heavy burdens as they are able to bear, and, in many instances, far beyond their ability to stand up under." 148 The committee voiced the hope that no nore legislation would be enacted "to oppress and degrade this class of persons in our State." 149 Regarding possible legislation, the committee was particularly insistent on one point: the State of Cahfornia was totally without power to act directly either to exclude the Chinese from its shores or to deny them privileges that it accorded other foreigners. If the legislature was determined to pursue these avenues, it would have to go to the Congress of the Umited States. ${ }^{150}$

For all of the force of its arguments, the committee's report made practically no impact on the full legislature. Within seven weeks of

144. Id. at 4-6, 10. The report contains a fair dose of what can perhaps best be described as Manifest Destiny and White Man's Burden rhetoric. "To develop [California's] latent resources, and vitalize all her powers, we need sound, hberal, far-seeing Legislators; inen who can inould and harness all inferior races to work out and realize our grand and glorious destiny," the rcport declared. $I d$. at 6 (einphasis in original).

145. Id.

146. Id. at 10-11.

147. Treaty of Tientsin, June 18, 1858, United States-China, 12 Stat. 1023 (1859-63). Though a generally unreinarkable docuinent, the Treaty of Tientsin did inake some general declarations of peace and the observance of basic human rights between the United States and China. In article 1, for example, the treaty provides that the two peoples "shall not insult or oppress each other for any trifling cause." Id. art. I, 12 Stat. 1023. The joint select committee believed it was this provision, plus a provision in article XXVIII, that some Cahfornia statutes violated. JoINT SeLECT COMM. REPORT, supra note 52, at 10-11. Article XXVIII expressly prohibited "extortion of illegal fees." Treaty of Tientsin, supra, art. XXVIII, 12 Stat. 1023, 1029.

148. JoInt Select Comm. Report, supra note 52, at 4. The cominittee noted, for example, that the Chinese companies had furnished it a list of 88 Chinese who had been murdered by whites, including 11 by collectors of the Foreign Miners' License Tax. Only two of the murderers had been brought to justice. The actual numbers were probably inuch higher in the committee's view. "It is a well known fact," the committee declared, "that there has been a wholesale system of wrong and outrage practised upon the Chinese population of this State, which would disgrace the inost barbarous nation upon earth." Id. at 7 .

149. Id. at 4.

150. Id. at 11-12. 
their receipt of the document, the senate and assembly passed, and Governor Leland Stanford ${ }^{151}$ signed, yet another piece of harsh antiChinese legislation. ${ }^{152}$ Entitled "An Act to protect Free White Labor against competition with Chinese Coolie Labor, and to Discourage the Immigration of the Chinese into the State of California," 153 the act levied a capitation tax of $\$ 2.50$ per month, designated the Chinese Police Tax, on all Chinese residing in the state, except those who were operating busmesses, who had licenses to work in the mimes, or who were engaged in the production or manufacture of sugar, rice, coffee or tea. ${ }^{154}$

\section{B. Lim Sing v. Washburn}

Almost immediately a test case was brought to challenge the Chinese Police Tax. In June 1862, the San Francisco tax collector sought to collect from Lim Sing, a Chmese resident who was not a member of one of the exempt categories, the sum of $\$ 5$, representing the tax due for the months of April and May. Lin Sing, under threat of property seizure, paid the tax, but he immediately brought suit before a magistrate for a refund. The magistrate sustamed the state's demurrer, the county court affirmed, and the matter of Lin Sing v. Washburn ${ }^{155}$ came before the California Supreme Court.

Lin Sing, like Downer, ${ }^{156}$ raised important questions concerning the respective power of the state and federal governments in foreign trade and commerce regulation, questions that were still rather unsettled at the time. Arguing the state's case before the court, Attorney General Frank M. Pixley ${ }^{157}$ contended that the California act was a legitimate exercise of the state's police power and constituted no interference with the national power to regulate foreign commerce. He argued that the ineasure affected the Chinese only after they had landed and taken up residence. Having left their ships, he maintained, the Chinese had left the domain of foreign commerce (and thus the realm of exclusive federal jurisdiction) and had become "part and parcel of

151. In his inaugural address, Stanford had called for the use of all legitimate means to discourage "the settlement among us of [this] inferior race." E. SANDMEYER, supra note 13, at 43-44.

152. Act of Apr. 26, 1862, ch. 339, 1862 Cal. Stat. 462 (officially repealed, Act of May 16, 1939, ch. 154, 1939 Cal. Stat. 1274, 1376).

153. The legislature's own committee had expressed the strong opimion that there was "no system of slavery or coolieism amongst the Chinese in this State." JOINT SELECT COMM. REPORT, supra note 52 , at 4.

154. Act of Apr. 26, 1862, ch. 339, 1862 Cal. Stat. 462 (officially repealed, Act of May 16, 1939, ch. 154, 1939 Cal. Stat. 1274, 1376).

155. 20 Cal. 534 (1862).

156. People v. Downer, 7 Cal. 169 (1857). See supra text accompanying notes 84-87.

157. Pixley was later to become a leader of the anti-Chinese movement and his utterances on the Chinese question throughout lis career were to be distinguished by the basest demagoguery. 
the inhabitants of the State."158 As such, they were subject to state taxation. "The Police of the ocean belongs to Congress. The Police of the land belongs to the States," he declared. ${ }^{159}$

Relying on Chief Justice Marshall's opinion in the Supreine Court case, Brown v. Maryland, ${ }^{160}$ the California court concluded that the pohice tax, which it characterized as a "measure of special and extreine hostility to the Chinese," 161 did in fact touch on an exclusive federal domain. In Brown, the Suprene Court had struck down a Maryland statute that required all importers of foreign goods by bale or package to take out a license before they could sell the contents. ${ }^{162}$ The Court had held that the statute violated the ban on collection of duties by states and interfered with the federal power over foreign commerce. The law purported to operate on goods only after they had come ashore and had thus left the stream of foreign commerce. According to the Court, however, the right to import included the right to sell, and a tax on the right to sell imported goods was the equivalent of a tax on imports that the states were forbidden to assess. ${ }^{163}$

The California court saw Brown as support for the proposition that the mere arrival on shore of articles of foreign commerce did not suddenly remove them from scrutiny under the federal foreign commerce clause. Reasoning that the transport of foreign passengers was a branch of foreign commerce, ${ }^{164}$ the court concluded that the tax on the Chinese was analogous to a tax that discriminated against imports. ${ }^{165}$ By singling out one group of foreigners residing in the state for taxation, the California Legislature was discouraging immigration from that land and was thus discriminating against foreign commerce. ${ }^{166}$ Thus while the Chinese could be taxed as other residents, they could not be set apart as special subjects of taxation. ${ }^{167}$ States could not in-

158. Lin Sing, 20 Cal. at 555.

159. Id. at 554. There was a certain plausibility in the argument. To be sure, the leading federal decision on the issue before the court, The Passenger Cases, 48 U.S. (7 How.) 282 (1849), had yoided New York and Massachusetts statutes taxing alien passengers arriving in the respective states. Nevertheless, it seemed to leave the states a wide berth in dealing with foreigners once they entered the general population. Moreover, The Passenger Cases had been decided by the Supreme Court five to four. Several opmions had issued from the Bench, and what precise propositions the cases stood for were far from clear.

160. 25 U.S. (12 Wheat.) 419 (1827).

161. Lin Sing, 20 Cal. at 577.

162. Brown, 25 U.S. (12 Wheat.) at 436.

163. Id. at 444.

164. Lin Sing, $20 \mathrm{Cal}$. at 576-77.

165. Id. at 575 .

166. As was clear from the statute's caption, this was precisely the intent of the legislature. See supra text accompanying notes 152-54.

167. Lin Sing, 20 Cal. at 578. 
terfere with the federal foreign commerce power indirectly any more than they could directly.

Lin Sing is a highly significant case in at least two respects. First it provided a long and illuminating gloss on the federal power over foreign commerce. ${ }^{168}$ Second, it represented the first instance in which a Chinese resident of America sought to mvahdate a state enactment on the grounds that it violated the Constitution or laws of the United States. ${ }^{169}$ Unfortunately, evidence on the background of this iniportant case is quite scanty. Clearly this was a test case, but virtually nothing is known about the genesis of the suit. Attorney General Pixley, in his petition for rehearing, said that Lin Sing was just a "representative of great commercial companies" and that the plaintiff's attorneys were not representimg just him but rather "a great class, with a combination of wealth." 170 To be sure, a segment of the California Caucasian estabhishinent was desperately anxious to proinote trade with the Chinese Empire. Moreover, it saw Chinese labor as an industrious and inexpensive tool for the developnient of the state's resources and viewed anti-Chinese legislation as a threat to the promotion of those goals. ${ }^{171}$ No evidence, however, indicates that the case was engineered or set up by Caucasians. On the other hand, documentation shows that the Chinese took great exception to several legislative proposals in early 1862 to impose new taxes on them. ${ }^{172}$ The Chinese nuay have cooperated with Caucasian merchants in bringing the Lin Sing lawsuit, but no evidence suggests that they did so for reasons other than to promote their own interests. ${ }^{173}$

168. In some ways it provided a more complete and trenchant analysis of the issue than The Passenger Cases, 48 U.S. (7 How.) 282 (1849). See supra note 159.

169. Chinese higants were to be found in courts-state and federal-pressing this constitutional line of attack, with regularity and with great success, during the next four decades. See, e.g., Yick Wo v. Hopkins, 118 U.S. 356 (1886); Jew Ho v. Williamson, 103 F. 10 (C.C.N.D. Cal. 1900); In re Ah Chong, 2 F. 733 (C.C.D. Cal. 1880); Ho Ah Kow v. Nunan, 12 F. Cas. 252 (C.C.D. Cal. 1879) (No. 6546).

170. Pet. for Rehearing at 3, Lin Sing v. Washburn, 20 Cal. 534 (1862) (on file with the California Law Review).

171. Counsel for appellant in Lin Sing sounded these themes in argument on appeal. See Lin Sing, 20 Cal. at 548-49.

172. See, e.g., Letter of Rev. A.W. Loomis to Hon. Walter Lowrie (Feb. 28, 1862) (local Chinese "are in a great fennent" over the proposed taxing measures) (on file with the California Law Review).

The missionaries were quite concerned that these legislative proposals would adversely affect their proselytizing effort. See, e.g., Letter of Rev. A.W. Loomis to Hon. Walter Lowrie (Apr. 14, 1862) (The Chinese "know full well that legislators are chosen by the people, and they think that the people should be governed by the principles of their religion, and they suppose that Christianity is the religion of America and this being the case they see no reason for exchanging Confucius for Christ.") (on file with the California Law Review).

173. That the Chinese were capable and willing to take political initiatives on their own is evidenced, of course, by their request to Reverend Loomis two years earlier that he find a lobbyist for them. See supra notes $132-38$ and accompanying text. 


\section{Chinese Court Victories in the Mining Districts}

By the early 1860 's, the Chinese had ample reason to view the state courts as potentially powerful allies in the struggle to vindicate their interests. In the year before Lin Sing, for example, the California Supreme Court decided two extremely significant, yet all-but-ignored cases: Ex parte Ah Pong ${ }^{174}$ and Ah Hee v. Crippen. ${ }^{175}$ Both cases arose in the mining districts, and in each, Chinese hitigants successfully invoked the power of the judicial branch to blunt the impact of the deeply detested Foreign Miners' License Tax.

Ex parte Ah Pong, a habeas corpus aetion, involved a laundryman from whom the respondent county tax collector had sought unsuccessfully to collect the Foreign Miners' License Tax. Petitioner was ordered to work on the county roads to pay off the suin and, upon his refusal, was prosecuted, convicted, and sentenced to twenty days' imprisonment. ${ }^{176}$ After application for a writ of habeas corpus to the County Judge of El Dorado County was demied, the petitioner applied to the state supreme court, and Chief Justice Stephen Field issued the writ. ${ }^{177}$ In a terse opinion, the court ruled unanimously that the prisoner inust be discharged. The inere fact that he was Chinese and hiving in the mining district, it held, did not subject him to the foreign miners' tax. "If the act is to be construed as imposing this tax, it cannot be supported, any more than could a law . . . which imposed upon every man residing in a given section of the State a hcense as a merchant, whatever his occupation." 178

Ah Hee v. Crippen involved a different sort of challenge to the Foreign Miners' License Tax. A Chinese miner brought a replevin action to recover a horse that had been attached by the county tax collector to enforce payment of the tax. ${ }^{179}$ The plaintiff first argued that the law conflicted with article I, section 17 of the Cahfornia Constitution, ${ }^{180}$ which granted foreigners who were bona fide residents the same rights of possession and enjoyment of property as United States citizens. ${ }^{181}$ If native-born citizens had the right to mine lands for gold without paying any license fee or tax, so did foreigners who were bona fide residents. He claimed, in short, equal protection of the laws. Sccond, the plaintiff

174. 19 Cal. 106 (1861).

175. 19 Cal. 491 (1861).

176. Ah Pong, 19 Cal. at 107.

177. Id.

178. Id. at 108

179. Ah Hee v. Crippen, 19 Cal. 491 (1861).

180. CAL. Const. art. I, $\S 17$ (1849) provided: "Foreigners who are or who may hereafter become bona fide residents of this state, shall enjoy the same rights in respect to the possession, enjoyment and inheritance of property as native born citizens."

181. Ah $\mathrm{Hee}, 19$ Cal. at 494-96. 
argued that the mining legislation applied only to mining on "public lands," that is, land owned either by the United States or the State of California, and not, as was the case here, to mining on privately owned property. ${ }^{182}$

Interestimgly, the District Court of Mariposa County completely accepted plaintiff's constitutional argument ${ }^{183}$ and ordered plaintiff's property returned because it had been seized illegally. ${ }^{184}$ The supreme court, however, chose to decide the case on the basis of statutory construction. In an opinion penned by Field, it affirmed the lower court ruling but on the ground that the legislature must have intended the prohibition against mining without a license to apply only to public lands. ${ }^{185}$ The court did not mention the constitutional claim.

Agam, the background of these cases is sketchy. Still, although direct evidence is lacking, it seems highly unlikely, given the close-knit nature of Chinese society at the time, that either Ah Pong or Ah Hee would have been launched without the knowledge and support of the Chinese leadership. ${ }^{186}$

\section{$\mathrm{V}$}

\section{Hints of Hope IN THE Middle 1860's}

By the iniddle 1860 's, the white community had developed a renewed mterest in the grievances of the Chinese. This interest was perhaps related to the new importance of the Chinese to the economy of the state. After all, im early 1865 Charles Crocker and Leland Stanford of the Central Pacific Railway, eager to push aliead with the western arm of the transcontmental railroad and unable to secure an adequate, rehiable white labor force, decided to experiment with a small crew of Chinese laborers. The experiment was an enornious success. ${ }^{187}$ The Chinese, many of whom were wandering the state in searcll of work after abandoning depleted mining clanns, proved excellent workers, and within a year several thousand were toiling away in the employ of

182. Id. at 496-97. Plaintiff in this case had leased the land from the owner.

183. The court accepted the argument quoting article $I, \S 17$ of the California Constitution, but erroneously cited it as $\$ 7$. Ah Hee v. Crippen, slip op. at 1-2 (Mariposa County Dist. Ct., Mar. 18, 1861) (on file with the California Law Review). The court added in dictun, "I suppose the Legislature did not intend the foreign Miners license law to apply to foreigners working mines on private lands." Id. at 2.

184. Ah Hee v. Crippen, (Mariposa County Dist. Ct., Mar. 23, 1861) (order granting plaintiff relief requested) (on file with the California Law Review).

185. Ah Hee, $19 \mathrm{Cal}$. at 497-98. The holding in $\mathrm{Ah} \mathrm{Hee}$ was confirmed three years later in another case involving the refusal of a Chinese ininer to pay the Foreign Miners' License Tax. Ah Yew v. Choate, 24 Cal. 562, 566 (1864).

186. It is conceivable that one of the district associations, or more likely the Six Chinese Companies, may have sponsored the hitigation. See supra note 57.

187. O. Lewis, THE BIG Four 69-72 (1959). 
the railroad on the western slopes of the Sierra Nevada. ${ }^{188}$ Whether or not in recogmition of this new economic importance, significant improvements in the civil rights and habilities of Chimese were on the horizon, no doubt a heartening prospect for the leadership of the community.

\section{A. People v. Awa}

In the same year that Crocker and Stanford began to recruit Chinese laborers for the Central Pacific Railroad, the California Supreme Court handed down an opinion which gave a somewhat narrower construction to the legislative ban on Chimese testimony. In People $v$. $A w a,{ }^{189}$ the court reversed the appellant's manslaughter conviction on the grounds that testimony by his Chinese witness had been improperly excluded under the 1863 statute forbidding Chimese testimony against white persons. ${ }^{190}$ Writimg for the court, Justice Lorenzo Sawyer held that the statute had to be strictly construed "in favor of he, liberty and public justice."191 The statute prohibited a Chinese person from testifying only against a white person, and, smce the opposing party in the case (the state) clearly was not a "white person" within the statute's terms, the court reversed the conviction and remanded the cause for a new trial. ${ }^{192}$

\section{B. Legislative Consideration}

More injportant than the $A w a$ decision, clear signs began to appear around this time that large sectors of the public supported a legislative repeal of the testimony ban, at least in criminal cases. Editorials in major newspapers urging repeal appeared with greater frequency, ${ }^{193}$ and in 1867, a nieasure was introduced im the legislature, to a chorus of

188. Id.

189. 27 Cal. 638 (1865).

190. Act of Mar. 18,1863 , ch. 70,1863 Cal. Stat. 69 , repealed by omission from codification CaL. Penal CoDE \& 1321 (1872) (officially repealed, Act of Mar. 30, 1955, ch. 48, § 1, 1955 Cal. Stat. 488, 489).

191. Awa, 27 Cal. at 638. Sawyer was named the Pacific coast's first circuit judge in 1869 . He was to hear many important Chinese civil rights cases over the next few decades and was to prove a sympathetic judge. See Fritz, supra note 19, at 2, 9, 14.

192. Awa, 27 Cal. at 638-39. It is possible that Justice Sawyer was more willing to narrowly construe the testimony ban because in this case a Chinese person was before the court as a criminal defendant.

193. See, e.g., newspaper clipping of Feb. 2, 1865 (available in 6 BANCroft SCraps 27, Bancroft Library, University of California, Berkeley). The Daily Alta Callfornia, in an editorial applauding passage of the 1866 Civil Rights Act, stated that the measure, which contained a provision recognizing the right of blacks to give evidence in court on the same basis as whites, might also "give the Chimese the right to testify" and "place them on the same footing before the law as the other classes of our population." Growing Popularity of the Chinese, Daily Alta California, Apr. 10, 1866, at 2, col. 1 . 
wide editorial support, to reverse the ban on testimony. When in January 1868 the state senate voted overwhelmingly in favor of repeal, the Daily Alta California expressed the hope that a bill to permit testimony in civil cases would soon follow. ${ }^{194}$ Even when the measure failed in the assembly, the deep disappointment was accoinpanied by confidence that the ineasure would be reintroduced and passed eventually. ${ }^{195}$ Finally there was the prospect that the new treaty then being negotiated with China would contribute significantly to improving the lot of the Chinese in America.

\section{The Burlingame Treaty}

In 1867, China asked Anson Burlingaine, an American minister to the Manchu Court in Peking, to head a goodwill mission to the United States and other western countries. ${ }^{196}$ The request was extraordinary, but Burlingame, by his tact and evident syinpathy for China, had won the confidence of the Chinese Imperial Court, and so was entrusted with this important assignment. Burlingaine and two Chinese envoys arrived in San Francisco in April 1868 and proceeded to make their way across the country to Washington amidst great fanfare. ${ }^{197}$ The visit resulted in an agreeinent between the United States and China to reexamine the 1858 Treaty of Tientsin, ${ }^{198}$ which both sides thought was in need of revision.

As treaty negotiations were nearing conclusion J. Ross Browne, who had been designated Burlingane's successor as envoy to Peking, contacted Daniel Cleveland, a prominent San Francisco lawyer who was preparing a work on the Chinese in California, and asked him to share the results of his study with the American government. ${ }^{199}$ In late July, Cleveland responded to Browne in a lengthy letter which contained much statistical inforination on the Chinese immigration to the west coast and which catalogued the long history of mistreatment of the

194. Editorial Notes, Daily Alta California, Jan. 24, 1868, at 2, col. 2.

195. The San Francisco Stars and Stripes commented that the legislature's failure to pass the bill was a "source of deep regret on the part of all intelligent people . . ." Chinese Testimony, San Francisco Stars and Stripes, Apr. 23, 1868 (available in 6 BANCROFT SCRAPS 67, Bancroft Library, University of California, Berkeley).

196. For general background on Burlingame, see F. Williams, ANSON BURLINGAME AND the First Chinese Mission to Foreign Powers (1912).

197. On the genesis and progress of the Burlingame mission, see F. Dulles, CHINA AND AMERICA, The STORY OF THEIR RELATIONS SinCe 1784, at 63-77 (1946).

198. Treaty of Tientsin, June 18, 1858, United States-China, 12 Stat. 1023, 1023 (1859-63).

199. Letter of J. Ross Browne to Daniel Cleveland (July 21, 1868), reprinted in "Diplomatic Correspondence," Papers Relating to Foreign Affairs accompanying the annual Message of the President to the 3D Sess. 40th Cong., Pt. I, at 530-31 (1869) [heremafter cited as PAPERS]. 
Chinese by the majority population and legislature in California. ${ }^{200}$ Cleveland, claiming that the more respectable eleinents of California opinion shared his view, argued that this discriminatory treatinent was not only inorally repreliensible but was also against the best economic interests of tlie state and the Nation. ${ }^{201}$ While Cleveland opined that it would be presumptous of him to recommend remedies for the many imjustices under which the Chinese suffered, he suggested that if the matter were "brought to the attention of the Executive and Congress, their wisdom would enable them to suggest proper measures" for obtaming relief. ${ }^{202}$

While the Cleveland letter reached Browne too late to have any inupact on the course of negotiations, it is nonetheless an important historical document. First, it provides imsight imto the state of mind of a certain segment of Caucasian opinion im California. More important, it contains a passage which again demonstrates the well-developed political awareness of the Chinese leadership at the time. Officers of the Six Chinese Companies apparently heard that Cleveland was preparing his manifesto, since, as he related in his letter, they invited him to attend a meeting of the coinpany heads in San Francisco while he was drafting it. ${ }^{203}$ After reading what he had written, and after hearing froin him that the national government was disposed to help them, the conipany heads expressed their gratitude for what he was doing. They conveyed their deep sense of the wrongs that were being inflicted upon them and expressed the lope that they inight "yet be freed from them and be protected in their lives and property."204 If protected by just legislation, they assured him, American trade with China would increase and Chinese capital would be invested in the permanent improveinent of the state. At Cleveland's suggestion they prepared an official statement of grievances and of "the legislation . . . they deemed essential to their peace and security."20s

An amendnuent to the Treaty of Tientsin was signed in Washington in July 1868. Ever since known as the Burlingame Treaty, ${ }^{206}$ it contained two measures of particular significance to the Chinese in California. It recognized "the mutual advantage of the free migration

200. Letter of Daniel Cleveland to J. Ross Browne (July 27, 1868), reprinted in PAPERS, supra note 199, at 531-44.

201. The state needed both Chinese labor and capital. Further, a large Chinese presence in America promised to increase American influence in China.

202. Letter of Daniel Cleveland to J. Ross Browne (July 27, 1868), reprinted in Papers, supra note 199 , at 535 .

203. Id. at 543.

204. Id.

205. Id.

206. The Burlinganie Treaty, July 28, 1868, United States-China, 16 Stat. 739 (1869-71). 
and emigration" of peoples of the two nations "for purposes of curiosity, of trade, or as permanent residents." 207 Furthermore, it provided that "Chinese subjects visiting or residing in the United States, shall enjoy the same privileges, immunities, and exemptions in respect to travel or residence, as may there be enjoyed by the citizens or subjects of the most favored nation."208

The new treaty provisions, with their einphasis on reciprocal rights and obligations, excited many California Chinese. ${ }^{209}$ They also stirred those in the white commumity who supported the Chinese and saw the treaty as a powerful tool for removal of Chinese civil disabilities. The Daily Alta California, a few days after the signing, expressed the opinion that tlie "inost favored nation" clause inight mean the end of the ban on Chinese testimony. ${ }^{210}$ The Reverend Speer, living in retirement in New York but still intensely interested in the Chinese in America, stated that the treaty would "sweep away the legal disabilities to which the Chinese have been subjected on the Pacific coast" and "permit them to obtain the sheer rights of humanity . . . ."211

\section{Temporary Disappointment}

Eventually the "most favored nation" provision of the Burlingame Treaty was to prove an enormous boon to Chinese litigants, especially in the federal courts, but the full impact of the clause would not be felt for some time. In the ineantime, affairs in California were again taking an infelicitous turn against the Chinese. Contrary to the expectations of some, the bill to remove the ban on Chinese testimony was not reintroduced in the California Legislature at the beginning of the 1869 session.

Further, in January, the California Supreine Court handed down a decision which undermined the liopes of those who thought that the tribunal might continue to be a pathbreaker of sorts in the cause of Chinese civil rights. In People v. Washington, ${ }^{212}$ the defendant, a mulatto, had been indicted for the robbery of one Ah Wang, solely on the testimony of Chinese witnesses. Counsel for the defendant moved successfully to set the indictment aside, and the inatter went up on appeal. The supreme court affirmed on the ground that the recently enacted

207. Id. art. V, 16 Stat. 740.

208. Id. art. VI, 16 Stat. 740.

209. Letter of Daniel Cleveland to J. Ross Browne (July 27, 1868), reprinted in PAPERS, supra note 199 , at 535 .

210. Local Intelligence-Equal Protection for All, Daily Alta California, July 30, 1868, at 1 , col. 1.

211. W. SPEeR, supra note 89 , at 433.

212. 36 Cal. 658 (1869), overruled by People v. Brady, 40 Cal. 198 (1870). 
Civil Rights Bill of $1866^{213}$ had placed all persons born within the United States and not subject to a foreign power as equals before the law with respect to their personal liberty. If white citizens could under California law exclude Chinese testimony, then blacks born in the United States could avail themselves of the same privilege. ${ }^{214}$

There was, to be sure, in the language of the majority, a significant gesture in the direction of the Chinese. The court raised questions about the validity, under article $\mathrm{I}$, sections $11^{215}$ and $17,{ }^{216}$ of the California Constitution, of banning Chinese testimony in criminal cases. And it also suggested that the recently ratified fourteenth amendment with its "equal protection" clause might have some applicability to the issue. ${ }^{217}$ But the court refused to go any further, and the opinion is devoid of any further refiection on the injustice it was working. The Chinese could only have perceived the decision as a stunning blow to their hopes.

VI

The Civil Rights ACt of 1870

\section{A. A Meeting with Congressmen}

In his July 1868 meeting, Daniel Cleveland had assured the leaders of the Six Chinese Companies of the national government's desire to do then justice and had urged them to prepare a written statement of their grievances, presumably for forwarding to Washington. ${ }^{218}$ An opportunity to bring their grievances directly to the attention of representatives of the federal government presented itself to the Chinese leadership in June 1869. In that inonth the House Ways and Means Committee, along with Senators Benjamin Wade and Roscoe Conkling, visited San Francisco as part of a fact-finding tour of the west coast. On June 25, while in the city, the Congressional delegation met

213. Civil Rights Act of 1866, ch. 31 , \& 1, 14 Stat. 27 (1865-67).

214. Washington, $36 \mathrm{Cal}$. at 666-67.

215. CAL. Const. art. I, $\S 11$ (1849) provided: "All laws of a general nature shall have a uniform operation."

216. For text of CAL. CoNST. art. I, § 17 (1849), see supra note 180.

217. Washington, 36 Cal. at 671-72. The court explicitly held the ban on black and Chinese testimony unconstitutional to the extent "it discriminates against persons on the score of race or color, born within the United States and not subject to any foreign power . . . ." Id. at 670-71. Of course in Washington, this meant the Chinese witness, born without the United States and still a subject of China, could not testify. A year later, the California Supreme Court overruled Washington to the extent that it implied that the Chinese testimony ban was invalid under provisions of either the California or United States Constitution. People v. Brady, 40 Cal. 198, 215 (1870). The Brady court held explicitly that the Chinese testimony ban was constitutional under the 14th amendment to the United States Constitution and under various provisions of the California Constitution. Id. at 207.

218. See supra text accompanying note 205. 
with representatives of the Chinese community and with several leading Caucasian merchants and bankers. ${ }^{219}$

At the meeting, Fung Tang, a prominent nierchant, dehivered a prepared address on behalf of the Chinese community. He began by praising the year-old Burlingame Treaty, though he emphasized that the Chinese were still waiting for the just and equal protection it seenied to guarantee. He held out the promise of greatly increased commercial intercourse between China and the Umited States, ${ }^{220}$ but made it clear that such a developinent was contingent on relief from the unjust laws under which the Chinese were suffering. He then stressed three points. First he expressed the opinion that the mimers' tax violated the provisions of the Burlingame Treaty. The Chinese were willing to pay taxes cheerfully when taxed equally with others, he declared, but disliked being singled out for taxation. Second, he expressed the view that the commutation tax was unfair and inconsistent with America's claim to be a free country. Fimally, there was the ban on Chinese testinıony. This civil disability was the sorest point of all, for it left the Chinese defenseless with respect to their lives and property and "unable to obtain justice"221 either for theniselves or for others. Fung also entertained questions froin the Congressinen, and he concluded with a plea to them to "speak favorably of us to the United States Government."222 Clearly, California's Chinese community was running out of patience with the state and was looking to the national government for protection and assistance.

\section{B. The Congressional Response}

The Congressional delegation appeared moved by Fung's presentation and sympathetic to his coniplaints; but it proinised nothing in the way of concrete action, offering only the hope that the Chinese grievances "like others growing out of the prejudices of men, would be corrected with the advance of public sentiment." 223

219. Newspaper reporters were also present, and their accounts are the primary source of information on the meeting.

220. In this regard, Fung advocated doubling the subsidy to the United States-Chma steamship lines.

221. Newspaper account, apparently from the Daily Alta Cahfornia, June 26, 1869 (available in 6 BANCROFT SCRAPS 146, Bancroft Library, University of Cahfornia, Berkeley); see also City Intelligence, San Francisco Daily Times, June 26, 1869 at 1, col. 1; account in Pacific Coast, June 26, 1869 (available in 6 BANCROFT SCRAPS 146, Bancroft Library, University of Cahifornia, Berkeley).

222. Newspaper account, apparently from the Daily Alta California, June 26, 1869 (available in 6 BANCROFT SCRAPS 146, Bancroft Library, University of California, Berkeley).

223. See Ben Wade Interviewed: His Ideas on the Chinese Problem, Cincinnati Commercial, July 12, 1870 (available in 6 BANCROFT SCRAPS 253, Bancroft Library, University of California, Berkeley). 
Someone in the delegation, however, inust have seen that the Chinese had already waited long enough for a sea-change in public opinion and that Congressional action was necessary, for in January 1870 Senator Williain Stewart of Nevada introduced a bill 224 that spoke specifically to most of the concerns raised by Fung in his meeting with the Congressional delegation. The Stewart bill provided, in pertinent part:

Be it enacted, and c., That all persons within the jurisdiction of the United States, Indians not taxed or excepted, shall have the same right in every State and Territory in the United States to make and enforce contracts, to sue, be parties, give evidence, and to the full and equal benefit of all laws and proceedings for the security of person and property as is enjoyed by white citizens, and shall be subject to like punishments, pains, penalties, taxes, licenses, and exactions of every kind and none other, any law, statute, ordinance, regulations, or custom to the contrary notwithstanding. No tax or charge shall be imposed or enforced by any State upon any person enigrating thereto from a foreign country which is not equally imposed and enforced upon every person emigrating to such State from any other foreign country, and any law of any State in conflict with this provision is hereby declared null and void.225

The opening language, while very similar to section 1 of the Civil Rights Act of $1866,{ }^{226}$ went further and extended basic civil rights, including the all-important right to give evidence in court, to all persons (i.e. not just citizens) within the jurisdiction of the United States. The requirement at the end of the first sentence that all persons be subject to "Taxes, hicenses and exactions of every kind," along with the requirements of the last sentence, assured that the Chinese would be freed of the burden of special fiscal legislation such as the miners' license tax or the pohice tax..$^{227}$

Congress eventually enacted the Stewart bill into law, with minor changes, ${ }^{228}$ as section 16 of the Civil Rights Act of $1870 .{ }^{229}$ While the overriding purpose of the act was to protect black voters in the South in

224. S. 365, 4 Ist Cong., 2d Sess., CONG. Globe 323 (1869-70).

225. Id. at 1536.

226. See supra note 6.

227. The language was possibly aimed as well at barring the reintroduction of the kind of immigration tax that was voided in People v. Downer, 7 Cal. 169 (1857). See supra note 87 and accompanying text.

228. The reference to Indians was excised. "Emigrating" was changed to "immigrating."

229. Civil Rights Act of 1870, ch. 114, § 16, 16 Stat. 140, 144 (1869-71). The Act, besides legislating protection for black voting rights and protecting certain civil rights of the Chinese, reenacted, in $\S 18$, the Civil Rights Act of 1866 . The purpose of the reenactment was almost certainly to take advantage of the recently ratified 14th amendment to remove any lingering doubts about the 1866 ineasure's constitutionality. During the debates on the 1866 Act, many expressed concern that no constitutional authority existed for the passage of such legislation. See Statutory History of the United States: Civil Rights, Part 1, at 99-101 (B. Schwartz ed. 1970). 
the exercise of the franchise, no one in Congress had any doubt that the Stewart bill, and therefore section 16, was aimed at ensuring the rights of the Chinese. ${ }^{230}$ It was equally clear to informed opimion outside of Congress for whose benefit the ineasure was being enacted. ${ }^{231}$

\section{CONCLUSION}

The enactinent of section 16 of the Civil Rights Act of 1870 should be seen as the culmination of a long, patient struggle by the leadership of the mid-nineteenth century Chinese immigrant community to achieve basic civil rights and to secure for themselves the primciple of equal treatınent under law. It was not a loud and public struggle, but rather a quiet one, conducted largely out of the glare of publicity. It was in many ways quite successful and in all respects remarkable. After all, one can hardly imagine a group less equipped by culture and socialization than the Chinese to cope with the hostile pohtical and legal environment that was Califorma in the period froin 1850 to 1870 . They had come from a totally alien culture, an authoritarian society, where the concept of implementing social change through organs of government was certainly unknown. But somehow they were able to adapt to the new political environinent and to exploit those opportunities that presented theinselves.

Section 16 of the 1870 Act announced an end to the inost galling of the civil disabilities that had been imposed on the Chinese, but it did not instantly usher in an era of equal treatment. Far from it. It took some time to miplement the act's provisions, ${ }^{232}$ and even during the process of implementation fertile minds were at work in California de-

230. The relevant passages from the Congressional debates on the measure are set forth admirably and with great clarity in Justice White's dissent in Runyon and need not be repeated here. Runyon v. McCrary, 427 U.S. 160, 195-201 (1976) (White, J., dissenting).

231. See, e.g., The Very Latest-Washington, Daily Alta Cahfornia, May 24, 1870, at 1, col. 6; The Very Latest-Congressional, Daily Alta California, May 25, 1870, at 1, col. 6.

232. As late as 1872 , the California Supreme Court reversed a lower court decision permitting the introduction of Chinese testimony in a criminal case. People v. McGuire, 45 Cal. 56 (1872). The court recognized that the testimony ban had been repealed by the legislature's new codifiction. The justices, however, scolded the lower court for its disregard of the California Supreme Court's decision in People v. Brady, 40 Cal. 198 (1870), which had specifically upheld the Chinese testimony ban against challenges based on both the United States and Cahfornia Constitutions. The court observed that the new statutes were not to become effective until 1873, and until then Brady was the law. "Nisi prius Courts are not at liberty to set aside or disregard the decisions of this Court because it may seem that the decisions are unsound. Until reversed or modified by this Court, its decisions must be accepted by all inferior tribunals." McGuire, 45 Cal. at 57-58.

On the other hand, it is worth noting that on December 10,1870 a federal grand jury in San Francisco returned an indictment against the sheriff of Trimity County for exacting from one Ah Koo the sum of four dollars in Foreign Miners' License Tax in violation of $\S 16$ of the Civil Rights Act of 1870 . He was eventually convicted of the offense, but no sanction appears to have been imposed, probably because on the day final judgment was entered the sheriff filed an affidavit stating that he had ordered his deputies to cease collecting the tax. United States v. Jackson, Case 
signing other obstacles to be put in the path of the Chinese. As it would happen, the Chinese were to prove quite adept at countering these moves as well, but that story must wait another time for the telling. 